\title{
MAG and OMgp Synergize with Nogo-A to Restrict Axonal Growth and Neurological Recovery after Spinal Cord Trauma
}

\author{
William B. J. Cafferty, ${ }^{1,2}$ Philip Duffy, ${ }^{1,2}$ Eric Huebner, ${ }^{1,2}$ and Stephen M. Strittmatter ${ }^{1,2,3}$ \\ ${ }^{1}$ Program in Cellular Neuroscience, Neurodegeneration, and Repair and Departments of ${ }^{2}$ Neurology and ${ }^{3}$ Neurobiology, Yale University School of Medicine, \\ New Haven, Connecticut, 06536
}

Functional recovery after adult CNS damage is limited in part by myelin inhibitors of axonal regrowth. Three molecules, Nogo-A, MAG, and OMgp, are produced by oligodendrocytes and share neuronal receptor mechanisms through NgR1 and PirB. While each has an axon-inhibitory role in vitro, their in vivo interactions and relative potencies have not been defined. Here, we compared mice singly, doubly, or triply mutant for these three myelin inhibitor proteins. The myelin extracted from Nogo-A mutant mice is less inhibitory for axons than is that from wild-type mice, but myelin lacking MAG and OMgp is indistinguishable from control. However, myelin lacking all three inhibitors is less inhibitory than Nogo-A-deficient myelin, uncovering a redundant and synergistic role for all three proteins in axonal growth inhibition. Spinal cord injury studies revealed an identical in vivo hierarchy of these three myelin proteins. Loss of Nogo-A allows corticospinal and raphespinal axon growth above and below the injury, as well as greater behavioral recovery than in wild-type or heterozygous mutant mice. In contrast, deletion of MAG and OMgp stimulates neither axonal growth nor enhanced locomotion. The triple-mutant mice exhibit greater axonal growth and improved locomotion, consistent with a principal role for Nogo-A and synergistic actions for MAG and OMgp, presumably through shared receptors. These data support the hypothesis that targeting all three myelin ligands, as with $\mathrm{NgR} 1$ decoy receptor, provides the optimal chance for overcoming myelin inhibition and improving neurological function.

\section{Introduction}

Neurological recovery after trauma to the adult mammalian CNS is limited by the inability of damaged axons to reconnect to their physiological targets. Axon regeneration is restricted by cell-autonomous factors (Bulsara et al., 2002; Szpara et al., 2007), by the astroglial scar (Yiu and He, 2006; Busch and Silver, 2007), and by CNS myelin (McGee and Strittmatter, 2003; Liu et al., 2006). Myelin-derived inhibitory proteins include Nogo-A (Chen et al., 2000; GrandPré et al., 2000; Prinjha et al., 2000), MAG (McKerracher et al., 1994; Mukhopadhyay et al., 1994), OMgp (Mikol and Stefansson, 1988; K. C. Wang et al., 2002), RGM (Hata et al., 2006), ephrinB3 (Benson et al., 2005), semaphorins (Moreau-Fauvarque et al., 2003), and netrins (Löw et al., 2008). Of these, Nogo-A, MAG, and OMgp have been studied most extensively. Though they do not share sequence homology, they do share receptor signaling pathways. Neuronal NgR1 binds and transduces signals from Nogo-A, MAG, and OMgp (Fournier et al., 2001; Domeniconi et al., 2002; Liu et al., 2002; K. C. Wang et al., 2002; Barton et al., 2003; Hu et al., 2005; Venkatesh et al., 2005; Laurén et al., 2007); additionally, NgR2 can also mediate MAG signaling (Venkatesh et al., 2005; Laurén et al., 2007). More recently, PirB has also been

Received Dec. 16, 2009; revised Feb. 6, 2010; accepted April 1, 2010.

This work is supported by research grants from the National Institutes of Health to W.B.J.C. and to S.M.S. and by a grant from the Falk Medical Research Trust to S.M.S. We thank Sha Mi of Biogenldec for providing 0Mgp-null mice, and Stefano Sodi for expert animal husbandry.

Correspondence should be addressed to Stephen M. Strittmatter, Cellular Neuroscience, Neurodegeneration, and Repair Program, 295 Congress Avenue, New Haven, CT 06536. E-mail: stephen.strittmatter@yale.edu.

DOI:10.1523/JNEUROSCI.6239-09.2010

Copyright $\odot 2010$ the authors $\quad 0270-6474 / 10 / 306825-13 \$ 15.00 / 0$ shown to bind and transduce signals from all three proteins in vitro (Atwal et al., 2008). Both NgR1 and PirB are implicated in adult brain plasticity separate from injury (McGee et al., 2005; Syken et al., 2006).

Though axon-inhibiting roles and receptor mechanisms for Nogo-A, MAG, and OMgp have been demonstrated in tissue culture, their relative contribution to the inhibitory activity associated with CNS myelin in vivo remains undefined. In spinal cord injury (SCI) studies, Nogo-A gene-deficient mice are reported to have increased axonal growth of both sprouting and regenerative patterns (Kim et al., 2003; Simonen et al., 2003); however, this phenotype varies with age (Kim et al., 2003; Simonen et al., 2003; Cafferty et al., 2007a), strain background (Dimou et al., 2006), genetic mutation (Zheng et al., 2003; Cafferty et al., 2007a; Steward et al., 2007), and type of lesion (Cafferty et al., 2007b). Mice deficient in OMgp display limited axon growth after SCI (Ji et al., 2008), and MAG-deficient mice show no enhancement of axonal growth after SCI (Bartsch, 1996). Because these proteins have shared receptors and cellular mechanisms, they may be at least partially redundant in myelin for limiting axonal growth after injury.

To assess functional redundancy and axon-inhibitory hierarchy between ligands, we compared mice with single $\left(\right.$ nogoab $\left.^{-/-}\right)$, double $\left(\mathrm{mag}^{-/-} \mathrm{omgp}^{-/-}\right)$, or triple (nogoab ${ }^{-/-} \mathrm{mag}^{-/-}$omg ${ }^{-/-}$) mutations in these myelin inhibitors. Analysis of myelin-induced inhibition of neurite outgrowth in vitro, axonal growth of corticospinal and raphespinal fibers in vivo, and behavioral studies produce similar findings. Nogo-A plays a demonstrable nonredundant role in limiting axonal growth, whereas MAG/OMgp do not. However, MAG/OMgp have a readily apparent axonal 
growth limiting effect on a Nogo-A-deficient background consistent with redundant, synergistic axonal growth inhibition.

\section{Materials and Methods}

Mice. nogoab ${ }^{\text {trap/trap }}$ mice have been described previously (Kim et al., 2003; Cafferty et al., 2007a) and were backcrossed to C57BL/6 for nine generations. This line contains a gene trap insertion in the largest nogoaselective exon and eliminates expression of Nogo-A and Nogo-B protein (Kim et al., 2003). The mag-/- mice were purchased from The Jackson Laboratory (identifier B6.Cg-Mag ${ }^{\text {tmlRod} / J) ~(B a r t s c h ~ e t ~ a l ., ~ 1995) ~ a n d ~}$ were intercrossed with omg $p^{-1-}$ mice maintained on a C57BL/6 background (Ji et al., 2008), until homozygote double knock-outs were produced. The $o m g p^{-1-}$ mice were a generous gift from Dr. Sha Mi of Biogen Idec. The $\mathrm{mag}^{-/-}$omg $\mathrm{p}^{-/-}$mice were then intercrossed with nogoab ${ }^{\text {trap/trap }}$ mice to produce nogoab $b^{\text {trap/trap }} \mathrm{mag}^{-/-}$omg $\mathrm{p}^{-/-}$mice. Single nogoab trap/trap $(\mathrm{N}-/-)$, double $\mathrm{mag}^{-/-} \mathrm{omgp}^{-/-}(\mathrm{MO}-/-)$,

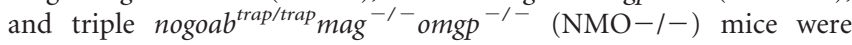
crossed with $\mathrm{C} 57 \mathrm{BL} / 6$ to produce respective single, double, and triple littermate heterozygotes.

Dorsal hemisection and corticospinal tract-tracing surgical procedure. Adult (2-4 months) female wild-type $(n=10)$, nogoab ${ }^{\text {trap/trap }}(n=12)$,

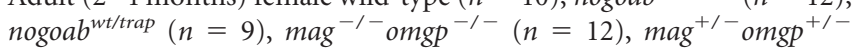
$(n=8)$, nogoab $^{\text {trap/trap }} \mathrm{mag}^{-1-}$ omgp ${ }^{-1-}(n=48$ dorsal hemisection, $n=8$ sham lesioned $)$, and nogoab ${ }^{\text {wt/trap }}$ mag $^{+/-}$omgp $^{+/-}(n=20$ dorsal hemisection, $n=20$ sham lesion) mice were deeply anesthetized with intraperitoneal ketamine $(100 \mathrm{mg} / \mathrm{kg})$ and xylazine $(15 \mathrm{mg} / \mathrm{kg})$. A laminectomy was performed to expose the dorsal portion of spinal cord corresponding to $\mathrm{T} 6$ and $\mathrm{T} 7$ levels. The dura mater was pierced, the spinal cord was exposed, and a pledget of gelfoam soaked in $1 \%$ lidocaine was placed on the exposed cord for 1 min before lesion. A dorsal hemisection lesion was performed at $\mathrm{T} 6$ with a 30 gauge needle and a pair of microscissors to a depth of $1.0 \mathrm{~mm}$ to completely sever the dorsal and dorsolateral corticospinal tract (CST). In one cohort of animals, the lesion depth was greater, $1.4 \mathrm{~mm}$, producing a near-total transection. For sham surgery, the laminectomy and exposure were identical, but no spinal cord lesion was created. The overlying muscle and skin was sutured with 4.0 vicryl.

Four weeks after spinal cord injury, mice received unilateral cortical injections with biotin dextran amine (BDA, 10,000 molecular weight, Invitrogen) to anterogradely label the corticospinal tract as described previously (Kim et al., 2003, 2004; Cafferty et al., 2007b). Briefly, burr holes were made over the sensorimotor cortex, and four microinjections were made to a depth of $1.0 \mathrm{~mm}$ (coordinates, $0.5-1.5 \mathrm{~mm}$ posterior to bregma and $0.5-1.5 \mathrm{~mm}$ lateral to bregma) to deliver a total volume of 1.2 $\mu \mathrm{l}$ of BDA. Six weeks after dorsal hemisection or sham lesion, mice were perfused with $4 \%$ paraformaldehyde. Postfixed overnight at $4^{\circ} \mathrm{C}$ and embedded in $10 \%$ gelatin for immunohistochemical processing.

Four animals were removed from the study due to incomplete lesions as determined by $>50 \%$ spared tissue by anti-GFAP staining (1 nogoab trap/trap, $1 \mathrm{mag}^{-/-}$omgp ${ }^{-/-}$, and 2 nogoab trap/trap $^{\text {mag }}{ }^{-/-}$ omgp ${ }^{-1-}$ mice).

Behavioral analysis. Mice that underwent dorsal hemisection lesions were assessed using the Basso Mouse Score (BMS) scale (Basso et al., 2006). All measurements were collected by observers unaware of genotype. Data are presented as average \pm SEM. Repeated-measures ANOVA with Tukey post hoc analysis was completed to assess statistical differences between genotypes. Subsequent ANOVA analysis was completed to assess differences between genotypes at each time point after lesion.

Immunoblotting. Cortex was freshly dissected from wild-type,

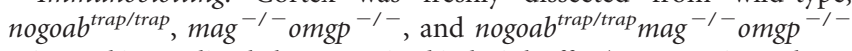
mice and immediately homogenized in lysis buffer (10 mM Tris/HCl, 1\% NP-40, $150 \mathrm{~mm} \mathrm{NaCl}, 0.1 \%$ SDS, $1 \%$ deoxycholate, supplemented with protease inhibitors) and sonicated, and the supernatant was collected after centrifugation at $100,000 \times g$ for $30 \mathrm{~min}$. Protein $(50 \mu \mathrm{g})$ was separated by SDS-PAGE and blotted onto PVDF. Membranes were probed with antibodies to detect Nogo-A (affinity-purified rabbit antiNogo-A) (X. Wang et al., 2002), MAG (1:1000, R\&D Systems), OMgp (1:1000, R\&D Systems), NgR1 (1:1000, R\&D Systems), myelin basic protein (MBP) (1:2500, Sigma), and GAPDH (1:25,000, Sigma). Immuno- reactivity was visualized with anti-rabbit, anti-goat, and anti-mouse IRDye 680 - or 800- (1:10,000, Rockland) conjugated secondary antibodies. Protein bands were detected with the Li-Cor Odyssey system (Li-Cor Biosciences).

Neurite outgrowth. Adult wild-type dorsal root ganglia neurons were dissociated as previously described (GrandPré et al., 2000). Dorsal root ganglion (DRG) cells were cultured in poly-D-lysine-precoated 96-well plates (Biocoat, Becton Dickinson Labware), which had been preincubated with myelin and laminin. Myelin was prepared (Norton and Poduslo, 1973; Robak et al., 2009) and extracted with $60 \mathrm{~mm}$ CHAPS (Spillmann et al., 1998) before dialysis against $10 \mathrm{~mm}$ HEPES, $150 \mathrm{~mm}$ $\mathrm{NaCl}, \mathrm{pH}$ 7.4. One hundred microliters of $10 \mu \mathrm{g} / \mathrm{ml}$ extracted myelin from wild-type, nogoab ${ }^{\text {trap/trap }}, \mathrm{mag}^{-{ }^{-}}$omg $p^{-/-}$, and nogoab ${ }^{\text {trap/trap }}$ $\mathrm{mag}^{-1-}$ omgp ${ }^{-\prime-}$ mice and vehicle (dialyzed extraction buffer alone) were incubated in each experimental well of a 96-well tissue culture plate for $2 \mathrm{~h}$ at $37^{\circ} \mathrm{C}$. Myelin extracts were then aspirated and immediately replaced with $100 \mu \mathrm{l}$ of $10 \mu \mathrm{g} / \mathrm{ml}$ laminin (Sigma). After a further $2 \mathrm{~h}$ of incubation at $37^{\circ} \mathrm{C}$, laminin was aspirated. Wells were washed once with DMEM (Invitrogen) and immediately flooded with culture media (DMEM + B27, Invitrogen) containing dissociated DRG cells. Cells were cultured for $18 \mathrm{~h}$ at $37^{\circ} \mathrm{C}$ and $5 \% \mathrm{CO}_{2}$, after which time they were fixed by addition of an equal volume of $8 \%$ paraformaldehyde in $20 \%$ sucrose for $1 \mathrm{~h}$, and then washed with PBS. Cells were stained with antibodies to $\beta$ III-tubulin (1:5000, Promega) and visualized with Alexa Fluor 488conjugated secondary antibodies. Analysis of neurite outgrowth was completed using ImageExpress automated imaging and neurite measurement algorithms without subjective input from the experimenter. Myelin was prepared independently from four mice of each genotype. Each independent myelin preparation was exposed to wild-type DRG cells from four different mice with each preparation tested in quadruplicate on 4 separate days. Data are presented as mean neurite outgrowth \pm SEM from 64 wells for each myelin genotype. In each well, >50 neurons were measured, and average outgrowth per well was calculated, so that in total $>3000$ neurons were included in each measurement.

Histology. Gelatin-embedded brain and spinal cord were cut on a vibratome (Leica Microsystems, VT1000), and free-floating sections were collected and stored in PBS $/ 0.01 \%$ sodium azide. Sections $(30 \mu \mathrm{m})$ of brain and spinal cord were immunostained with antibodies to detect myelin (1:200, Brain Stain Kit, Invitrogen), NeuN (1:1000, Millipore), 5-HT (1:5000, Immunostar), and GFAP (1:10,000, DAKO) with appropriate Alexa Flour 488- or 568- (Invitrogen) conjugated secondary antibodies. BDA detection was completed as previously described (Kim et al., 2003), using a nickel-enhanced diaminobenzidine (DAB) reaction. DAB and immunofluorescent images were collected on a Z1 Imager Zeiss microscope equipped with Apotome (Zeiss).

Anatomical analysis. All anatomical assessments were made by an observer unaware of the genotype.

For quantification of BDA + CST axons crossing the midline, five randomly chosen transverse sections of cervical spinal cord were collected from each of 8-10 mice of each genotype and processed to visualize BDA+ CST axons with DAB. The average number of crossing fibers was recorded for each animal. Data represents average number of axons clearly crossing through lamina $\mathrm{X} \pm$ SEM. Statistical significance was assessed using ANOVA with Tukey post hoc analysis.

For quantification of the number of CST fibers growing up to and past the lesion site, half of all the sagittal sections from each mouse $(\sim 20$ sections) were processed to visualize BDA + CST axons with DAB. The sum of axons crossing perpendicular lines at 3 and $1 \mathrm{~mm}$ rostral to the lesion and $0,1,2$, and $3 \mathrm{~mm}$ caudal to the lesion was recorded in all 20 sections from each animal. Data represent the average raw number of axons \pm SEM. Statistical significance was assessed using ANOVA with Tukey post hoc analysis.

The density of 5-HT-IR raphespinal innervation of ventral horn was determined using NIH ImageJ version 1.62. Labeled fibers were selected by thresholding, and average fiber length within gray matter was measured after using the skeletonize function in five sections from each mouse. Data represents average 5-HT density \pm SEM/ genotype. Statistical significance was assessed using ANOVA with Tukey post hoc analysis. 
A
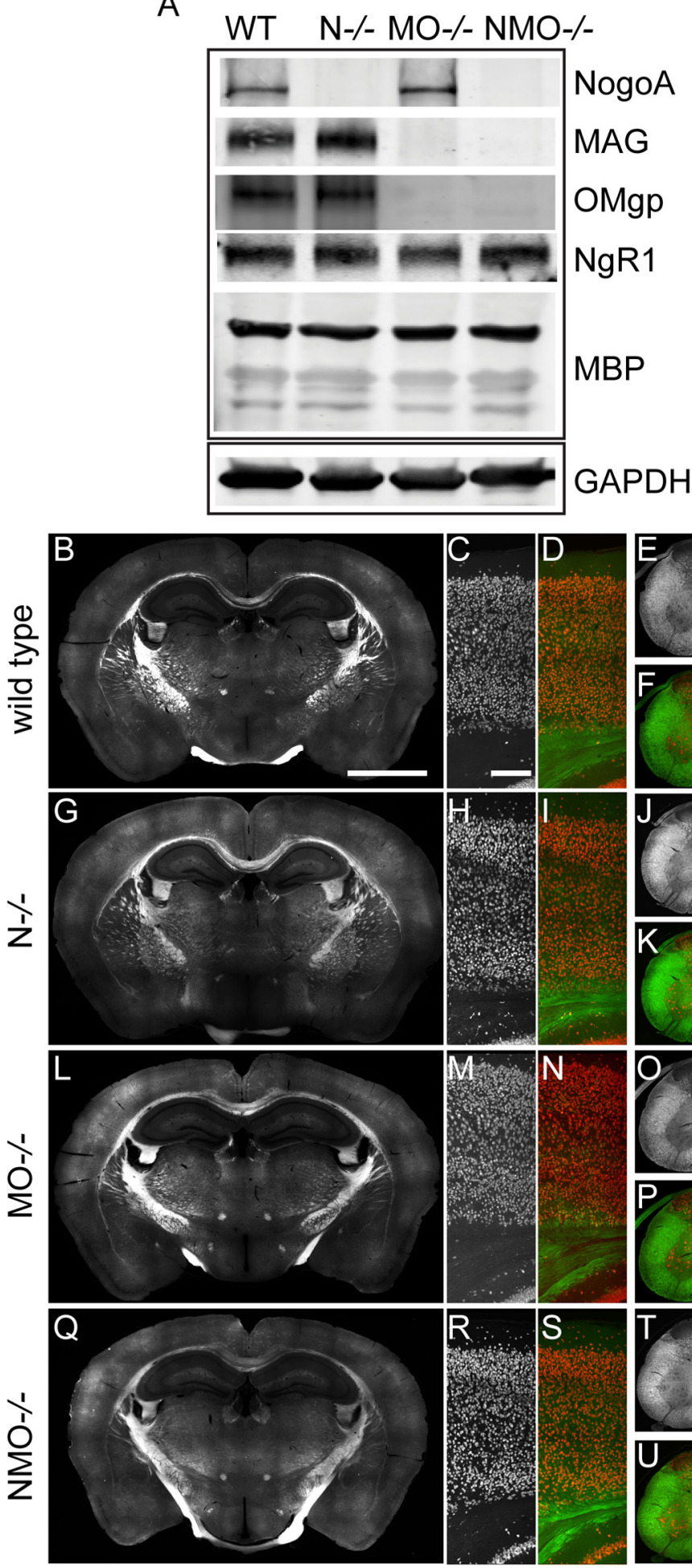

Myelin
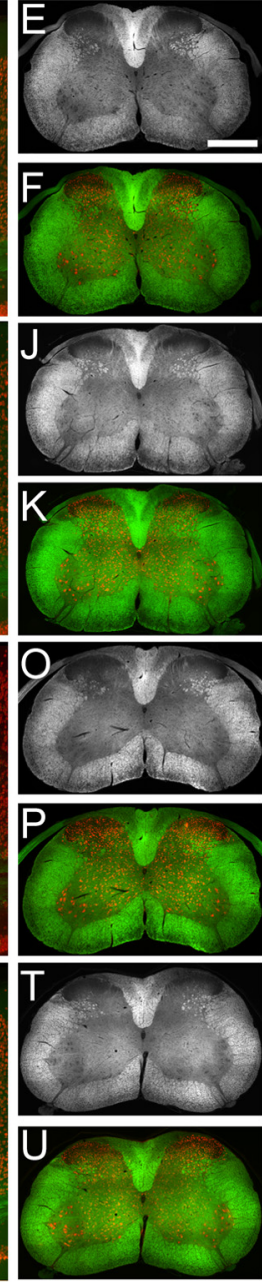

Myelin NeuN

Figure 1. nogoab $b^{\text {trap/trap }} \mathrm{mag}^{-/-}$omgp ${ }^{-/-}$mice have normal brain anatomy. $\boldsymbol{A}$, Immunoblot of cortical brain lysates from adult wild type, nogoab ${ }^{\text {trap/trap }}$, mag $^{-/-}$omgp ${ }^{-/-}$, and nogoab $b^{\text {trap/trap }}$ mag $^{-/-}$omgp ${ }^{-/-}$detecting Nogo-A, MAG, OMgp, Nogo receptor-1, MBP, and GAPDH. Photomicrographs illustrate comparable myelin staining (white and green) in coronal sections of brain and cervical spinal cord in wild-type $(\boldsymbol{B}, \boldsymbol{D}, \boldsymbol{E}, \boldsymbol{F})$, nogoab ${ }^{\text {trap/trap }}(\boldsymbol{G}, \boldsymbol{I}, \boldsymbol{J}, \boldsymbol{K}), \mathrm{mag}^{-/-}$omgp $^{-/-}(\boldsymbol{L}, \boldsymbol{N}, \mathbf{O}, \boldsymbol{P})$, and nogoab ${ }^{\text {trap/trap }} \mathrm{mag}^{-/-}$omgp $^{-/-}(\boldsymbol{Q}, \boldsymbol{S}, \boldsymbol{T}, \boldsymbol{U})$ mice. Higher-power photomicrographs of motor cortex reveal comparable neuronal (NeuN, red and white) density and architecture in wild-type $(\boldsymbol{C}, \boldsymbol{D})$ nogoab ${ }^{\text {trap/trap }}(\boldsymbol{H}, \boldsymbol{I})$, mag $^{-{ }^{-}-\mathrm{omgp}^{-/-}}(\boldsymbol{M}, \boldsymbol{N})$, and nogoab $^{\text {trap/trap }}$ mag $^{-/-}$omgp $^{-/-}(\boldsymbol{R}, \mathbf{S})$ mice. Scale bars: $\boldsymbol{B}$ (for $\left.\boldsymbol{B}, \boldsymbol{G}, \boldsymbol{L}, \mathbf{Q}\right), 2 \mathrm{~mm} ; \boldsymbol{C}($ for $\boldsymbol{C}, \boldsymbol{D}, \boldsymbol{H}, \boldsymbol{I}, \boldsymbol{M}, \boldsymbol{N}, \boldsymbol{R}, \boldsymbol{S}), 200 \mu \mathrm{m} ; \boldsymbol{E}$ (for $\boldsymbol{E}$, $\boldsymbol{F}, \boldsymbol{J}, \boldsymbol{K}, \mathbf{0}, \boldsymbol{P}, \boldsymbol{T}, \boldsymbol{U}), 500 \mu \mathrm{m}$.

Lesion depth was assessed in five sagittal sections from each lesioned mouse using GFAP immunoreactivity to delineate the lesion margins. We measured the dorsoventral extent of hyperfilamentous GFAP-IR for each animal. Animals that illustrated $<50 \%$ hyperfilamentous GFAP-IR in the dorsoventral axis were removed from the study (one $\mathrm{NMO}-/-$ mouse and two $\mathrm{NMO}+/-$ mice). Data represents average GFAP-IR depth \pm SEM/genotype. Statistical significance was assessed using ANOVA with Tukey post hoc analysis.

\section{Results}

Mice lacking Nogo-A/B, MAG, and OMgp are viable and display normal CNS architecture

To ascertain the interactions and the relative potencies of Nogo, MAG, and OMgp to inhibit axon growth, we generated single-, double-, and triple-null mutant mice for Nogo (N-/-), MAG/OMgp $(\mathrm{MO}-\mathrm{l}-)$, and Nogo/MAG/OMgp (NMO-/-), respectively. The $\mathrm{mag}^{-1-}$ mice (Bartsch et al., 1995) were bred with omgp ${ }^{-1-}$ mice (Ji et al., 2008) and backcrossed until homozygote double mutants were generated. Progeny from mag/omgp double knock-outs were intercrossed with the nogoab ${ }^{\text {trap/trap }}$ mice (Kim et al., 2003; Cafferty et al., 2007a) to produce nogo ${ }^{\text {trap/trap }}$ $\mathrm{mag}^{-/-} \mathrm{omgp}^{-/-}$triple knock-out mice. Western blot analysis of cortical brain lysate confirms the absence of Nogo-A in single-mutant mice, of MAG and OMgp in double-mutant mice, and of all three ligands in the triple-mutant mice (Fig. 1A). Expression of MBP and NgR1 is similar in the mutant mice in comparison to wild-type mice.

Discrete myelin abnormalities at particular ages have been reported for each of these three mutant strains ( $\mathrm{Li}$ et al., 1994; Montag et al., 1994; Bartsch, 1996; Huang et al., 2005; Pernet et al., 2008), so we considered whether the double- or triple-mutant mice might display more pronounced abnormalities in overall CNS myelination. Regional patterns of myelination assessed by antiMBP staining in brain and spinal cord of nogoab traptrap (Fig. 1G,E), $\mathrm{mag}^{-/-}$ omgp ${ }^{-1-}$ (Fig. $\left.1 L, O\right)$, and nogoab trapttrap mag $^{-1-}$ omgp $^{-1-}$ (Fig. 1Q,T) mice are identical to that observed in wild-type mice (Fig. 1B,C). Furthermore, there is no qualitative difference in cortical or medullary spinal cord neuronal number or distribution in nogoab trap/trap (Fig. 1H,I,K), mag $^{-1-}$ omgp $^{-1-}$ (Fig. $1 M, N, P$ ), and nogoab ${ }^{\text {trap/trap }}$ $\mathrm{mag}^{-1-} \mathrm{omgp}^{-1-}$ (Fig. 1R,S,U) mice. Thus, neuronal development is remarkably normal in mice lacking all three myelin inhibitors. 

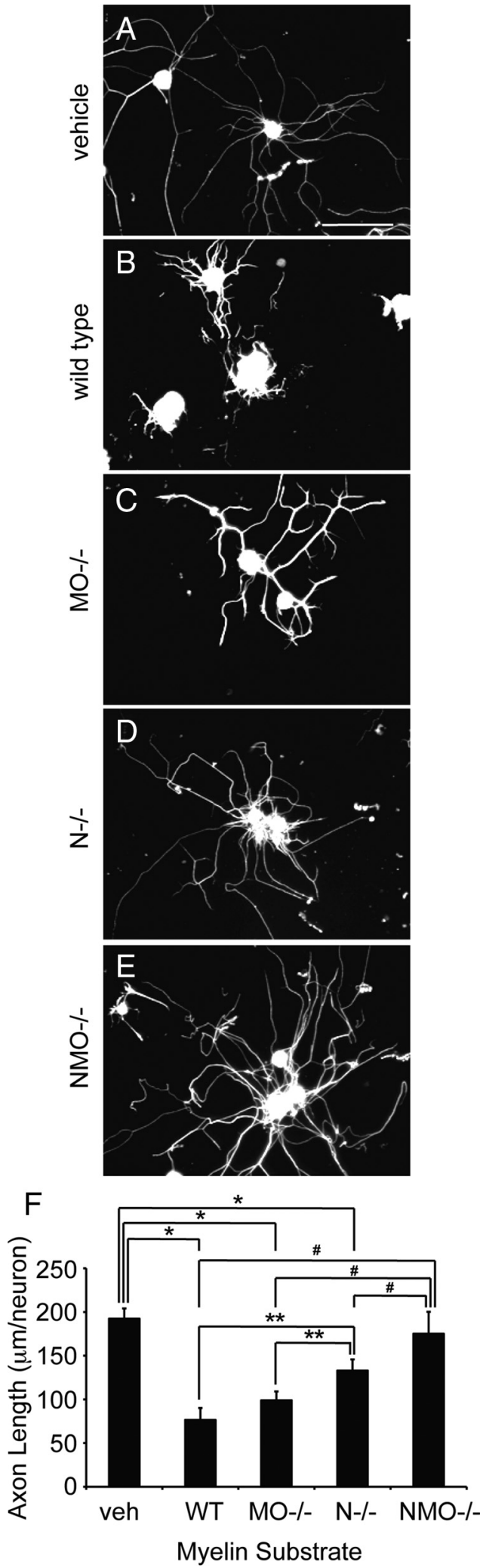

Figure 2. Extracted myelin from nogoab trap/trap $\mathrm{mag}^{-/-}$omgp $^{-/-}$mice is a less potent inhibitor of DRG neurite outgrowth. $\boldsymbol{A}-\boldsymbol{E}$, Photomicrographs of adult wild-type DRG cells immunostained for $\beta$ III tubulin after being cultured for $18 \mathrm{~h}$ on substrates coated with vehicle $(\boldsymbol{A})$ or myelin extracted from wild-type $(\boldsymbol{B}), \mathrm{mag}^{-/-} \mathrm{omgp}^{-1-}(\boldsymbol{C})$, nogoab ${ }^{\text {trap/trap }}(\boldsymbol{D})$, and nogoab trap/trap $\mathrm{mag}^{-1-}$ omgp $^{-/-}(\boldsymbol{E})$ mice. Quantification of neurite outgrowth $(\boldsymbol{F}$, data are presented as mean neurite length in micrometers per neuron \pm SEM) shows that DRG cells grown on a vehicle substrate had significantly longer average neurite extension than cells grown on myelin extracted from wild-type $(\boldsymbol{B})$, mag $^{-/-}$omgp $^{-1-}(\boldsymbol{C})$, and nogoab ${ }^{\text {trap/trap }}$
Synergistic CNS myelin inhibition of neurite outgrowth by MAG/OMgp is revealed in absence of Nogo-A

CNS myelin inhibition of neurite outgrowth from CNS or PNS neurons is readily detected in tissue culture (Schwab and Thoenen, 1985; Savio and Schwab, 1989). To investigate the relative roles of Nogo, MAG, and OMgp in this inhibition, we prepared myelin extracts from nogoab trap/trap, $\mathrm{mag}^{-/-} \mathrm{omgp} \mathrm{p}^{-1-}$, and nogoab ${ }^{\text {traptrap }} \mathrm{mag}^{-1-} \mathrm{omgp}^{-1-}$. Dissociated DRG neurons from adult wild-type mice were cultured for $18 \mathrm{~h}$ on 96 -well tissue culture plates upon which $1 \mu \mathrm{g}$ of extracted myelin from wildtype mice, nogoab trap/trap mice, $\mathrm{mag}^{-/-}$omgp $^{-/-}$mice, and nogoab ${ }^{\text {trap/trap }} \mathrm{mag}^{-/-}$omgp $^{-/-}$mice and dialyzed extraction buffer (vehicle) had been adsorbed without dehydration. DRG cells grown on plates coated with vehicle extend neurites with an average total length of $192.5 \pm 11.6 \mu \mathrm{m}$ (Fig. $1 A, F$ ), while cells grown on wild-type myelin exhibit significantly reduced outgrowth with average total neurite length per well of $76.5 \pm 13.5$ $\mu \mathrm{m}$ (Fig. $2 B, F)\left({ }^{*} p<0.01\right.$, ANOVA). Myelin prepared from $\mathrm{mag}^{-1-}$ omgp $^{-1-}$ mice (Fig. $2 C, F$ ) exhibit a nonsignificant trend to less inhibition than wild-type myelin, suggesting that these proteins may have little role in myelin inhibition. In contrast, myelin prepared from nogoab ${ }^{\text {trap/trap }}$ mice is significantly less inhibitory for DRG neurite outgrowth in comparison to wild-type $\left(132.9 \pm 11.8 \mu \mathrm{m}\right.$ vs $76.5 \pm 13.5 \mu \mathrm{m},{ }^{* *} p<0.01$, ANOVA) and mag $^{-\prime-}$ omgp $^{-\prime-}$ myelin $(132.9 \pm 11.8 \mu \mathrm{m}$ vs $99 \pm 10 \mu \mathrm{m}$, ${ }^{* *} p<0.01$, ANOVA) (Fig. $\left.2 D, F\right)$, demonstrating an independent and predominant role for Nogo in myelin inhibition.

Because Nogo, MAG, and OMgp each interact with both $\mathrm{NgR} 1$ and PirB axonal receptors, we considered whether MAG and OMgp action might be uncovered in the absence of Nogo-A. Myelin prepared from nogoab trap/trap $\mathrm{mag}^{-1-}$ omgp $^{-1-}$ mice is significantly less inhibitory to neurite outgrowth (Fig. $2 E, F$ ) than wild-type myelin (175.1 $\pm 25 \mu \mathrm{m}$ vs $76.5 \pm 13.5 \mu \mathrm{m},{ }^{*} p<0.01$, ANOVA), $\mathrm{mag}^{-/-}$omgp $^{-/-}$myelin $(175.1 \pm 25 \mu \mathrm{m}$ vs $99 \pm 10$ $\mu \mathrm{m},{ }^{\#} p<0.01$, ANOVA), or nogoab ${ }^{\text {trap/trap }}$ myelin $(175.1 \pm 25$ $\mu \mathrm{m}$ vs $132.9 \pm 12.8 \mu \mathrm{m},{ }^{*} p<0.01$, ANOVA). Thus, the triplemutant preparation reveals a synergistic or ancillary role for MAG and OMgp in myelin limitation of axonal outgrowth on the Nogo-null background.

\section{Rostral CST sprouting after dorsal hemisection in myelin inhibitor mutant mice}

We sought to determine whether a similar relationship between Nogo/MAG/OMgp genotype and axonal growth exists in vivo after traumatic injury. Dorsal hemisection (DhX) of the thoracic spinal cord results in interruption of many descending motor and ascending sensory spinal tracts, such that lesioned mice lose function in their hindlimbs. Restoration of hindlimb function depends largely on the reestablishment of axonal communication across the spinal cord injury site, either directly via long distance growth of injured fibers around or through the lesion site, or indirectly through local growth of injured and intact fibers to create new bypass circuits. We assessed the contribution of Nogo, MAG, and OMgp to these various patterns of axon growth and recovery.

$\left({ }^{*} p<0.01\right.$, ANOVA) mice. Myelin from nogoab $b^{\text {trap/trap }}$ mice is significantly less inhibitory than wild-type and $\mathrm{mag}^{-1-}$ omgp $^{-1-}$ myelin (** $p<0.01$, ANOVA). Myelin extracted from nogo$a b^{\text {trap/trap }}$ mag $^{-1-}$ omgp ${ }^{-1-}$ mice was significantly less inhibitory to neurite outgrowth than wild-type, mag ${ }^{-1-}$ omgp $^{-1-}$, and nogoab traptrap myelin ( ${ }^{\#} p<0.01$, ANOVA), but insignificantly different from neurite extension observed on vehicle substrates. Scale bar, $100 \mu \mathrm{m}$. 


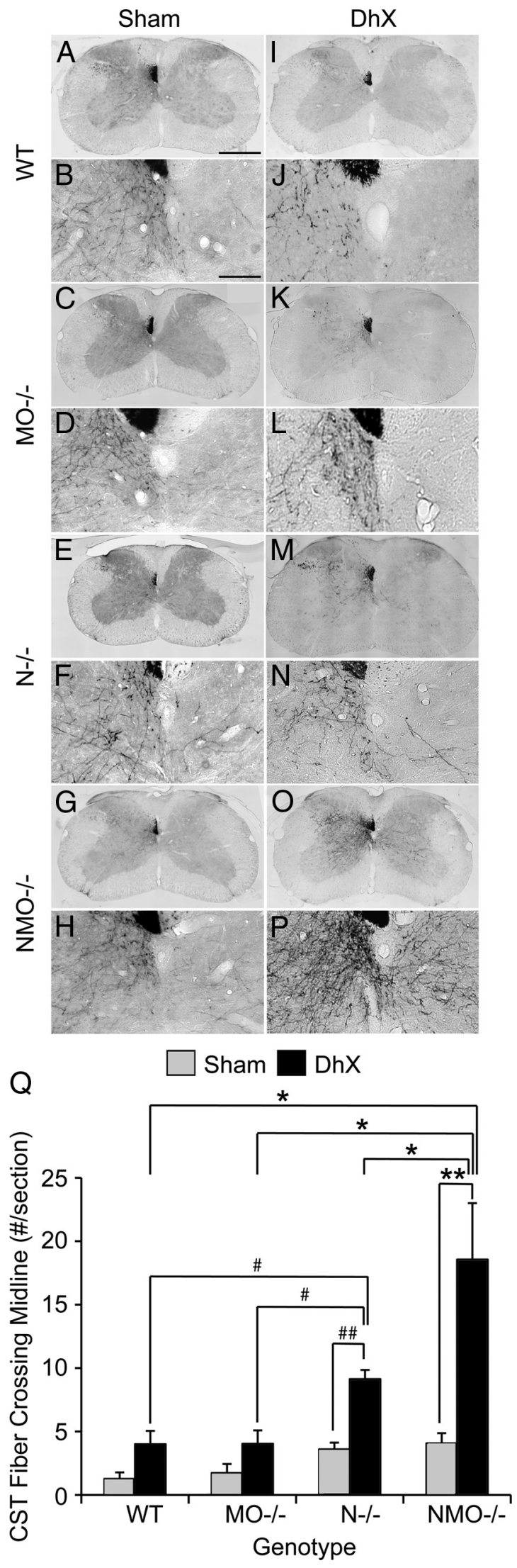

Figure 3. Bilateral sprouting of BDA+ CST fibers in cervical spinal cord after dorsal hemisection at T8 in nogoab ${ }^{\text {trap/trap }} \mathrm{mag}^{- \text {[supi]/ }}$ omgp ${ }^{- \text {[supi]/- }}$ mice. Photomicrographs $\boldsymbol{A}-\boldsymbol{P}$ illustrate BDA+ CST axons in cervical spinal cord from intact $(\boldsymbol{A}, \boldsymbol{B})$ and lesioned $(\boldsymbol{I}, \boldsymbol{J})$ wild-type mice, intact $(\boldsymbol{C}, \boldsymbol{D})$ and lesioned $(\boldsymbol{K}, \boldsymbol{L}) \mathrm{mag}^{-1-}$ omgp $^{-1-}$ mice, intact $(\boldsymbol{E}, \boldsymbol{F})$ and lesioned $(\boldsymbol{M}$, N) nogoab ${ }^{\text {trap/trap }}$ mice, and intact $(\boldsymbol{G}, \boldsymbol{H})$ and lesioned $(\boldsymbol{O}, \boldsymbol{P})$ nogoab ${ }^{\text {trap/trap }} \mathrm{mag}^{-/-} \mathrm{omgp}^{-/-}$
As a first step toward evaluating these multiple mechanisms, we measured the local growth of CST axons within the cervical enlargement at levels C5-C8, several millimeters rostral to the lesion in mice of multiple genotypes. We labeled the CST via BDA microinjection into the right motor cortex (supplemental Fig. S1, available at www.jneurosci.org as supplemental material). Uninjured intact wild-type (Fig. 3A,B), nogoab trap/trap (Fig. 3 E, F), $\mathrm{mag}^{-/-}$omgp ${ }^{-/-}$(Fig. 3C,D), and nogoab ${ }^{\text {trap/trap }}$ mag $^{-1-}$ omgp ${ }^{-1-}$ (Fig. 3G,H) mice displayed normal CST fasciculation in the ventral dorsal columns, termination of fibers in gray matter, and the sparse presence of fibers in the dorsolateral funiculi (Fig. 3A-H) in the cervical cord. There was no significant difference in the number of BDA + fibers observed crossing the midline and entering cervical spinal gray matter on the ipsilateral side of sham-lesioned wild-type, nogoab ${ }^{\text {trap/trap }}$, $\mathrm{mag}^{-/-}$omg $\mathrm{p}^{-/-}$, and nogoab trap/trap $_{\mathrm{mag}^{-/-} \text {omg }} \mathrm{p}^{-/-}$mice (Fig. 3Q, black bars). Six weeks after DhX, a small number of lesioned BDA + fibers are seen crossing the midline in wild-type (Fig. $3 I, J$ ) and $\mathrm{mag}^{-1-}$ omg $p^{-1-}$ (Fig. $3 \mathrm{~K}, L$ ) mice; however, the number differs insignificantly from sham-lesioned littermates (Fig. 3Q). Thus, injury may produce minor degrees of CST sprouting, but the absence of MAG and OMgp does not alter this growth, paralleling the neurite outgrowth assays in the presence of myelin (Fig. 2).

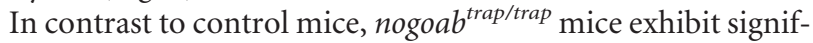
icantly increased numbers of BDA + CST fibers crossing the midline after DhX in comparison to intact and lesioned wild-type or $\mathrm{mag}^{-/-}$omg $p^{-/-}$mice, or intact nogoab ${ }^{\text {trap/trap }}$ mice (Fig. $3 M, N, Q)\left({ }^{*} p<0.001,{ }^{*} p<0.01\right.$, ANOVA). Even greater degrees of BDA+ CST sprouting across the midline are observed in nogoab ${ }^{\text {trap/trap }}$ mag $^{-/-}$omg $p^{-/-}$mice after DhX than in intact and lesioned wild-type, $\mathrm{mag}^{-/-}$omg $\mathrm{p}^{-/-}$, and nogoab trap/trap mice and intact nogoab ${ }^{\text {trap/trap }} \mathrm{mag}^{-1-}$ omg ${ }^{-1-}$ mice (Fig. 3O-Q) $\left({ }^{* *} p<0.001,{ }^{\# \#} p<0.01\right.$, ANOVA). The reproducibility of this phenotype is illustrated in supplemental Figure S2 (available at www.jneurosci.org as supplemental material). Thus, the absence of MAG/OMgp increases a Nogo-deficient postinjury axonal sprouting phenotype, and this matches the in vitro myelin inhibition of axonal growth (Fig. 2).

\section{CST regeneration after dorsal hemisection in nogoab ${ }^{\text {trap/trap }}$ mag $^{-/-}$omg $p^{-/-}$mice}

The sprouting of CST fibers in the cervical spinal cord of nogo$a b^{\text {trap/trap }}$ and nogoab $b^{\text {trap/trap }} \mathrm{mag}^{-/-}$omg $p^{-/-}$mice rostral to the T8 dorsal hemisection indicates that intact spinal gray and white matter are less inhibitory to axon growth. To test whether lesioned areas are more permissive for axon growth in nogoab ${ }^{\text {trap/trap }}$, $\mathrm{mag}^{-/-}$omg $\mathrm{p}^{-1-}$, and nogoab trap/trap $_{\mathrm{mag}^{-/-} \text {omgp }}^{-/-}$mice than in wild-type mice, we assessed the growth of BDA+ CST

mice. BDA + fibers can be seen exiting the contralateral dorsal column and arborizing in both dorsal and ventral gray matter, and remaining mostly unilateral in all genotypes. There was no significant difference in the number of BDA + CST axons that crossed the midline in the cervical cord after sham lesion in wild-type, nogoab ${ }^{\text {trap/trap }}$, mag $^{-1-}$ omgp ${ }^{-1-}$,

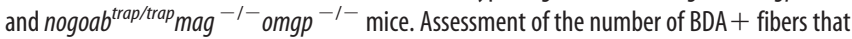
cross the midline after DhX (Q) revealed that significantly more CST fibers sprouted ipsilaterally in nogoab ${ }^{\text {traptrap }}\left(\# p<0.01\right.$, ANOVA) than in sham-lesioned nogoab ${ }^{\text {trap/trap }}$ mice and lesioned wild-type and $\mathrm{mag}^{-1-}$ omgp $^{-1-}$ mice ( ${ }^{\#} p<0.01$, ANOVA). Lesioned nogoab ${ }^{\text {trap/trap }}$ mag $^{-1-}$ omgp ${ }^{-l-}$ mice revealed significantly more CST fibers crossing the midline than sham-lesioned nogoab ${ }^{\text {trap/trap }} \mathrm{mag}^{-1-}$ omgp $^{-1-}$ mice $\left({ }^{* *} p<0.01\right.$, ANOVA) and lesioned wild-type, nogo$a b^{\text {trap/trap }}$, and mag $^{-1-}$ omgp $^{-1-}$ mice ( ${ }^{*} p<0.01$, ANOVA). Scale bars: $\boldsymbol{A}$ (for $\boldsymbol{A}, \boldsymbol{C}, \boldsymbol{E}, \boldsymbol{G}, \boldsymbol{I}, \boldsymbol{K}$, $\boldsymbol{M}, \mathbf{0}), 500 \mu \mathrm{m} ; \boldsymbol{B}$ (for $\boldsymbol{B}, \boldsymbol{D}, \boldsymbol{F}, \boldsymbol{H}, J, L, N, \boldsymbol{P}), 100 \mu \mathrm{m}$. 

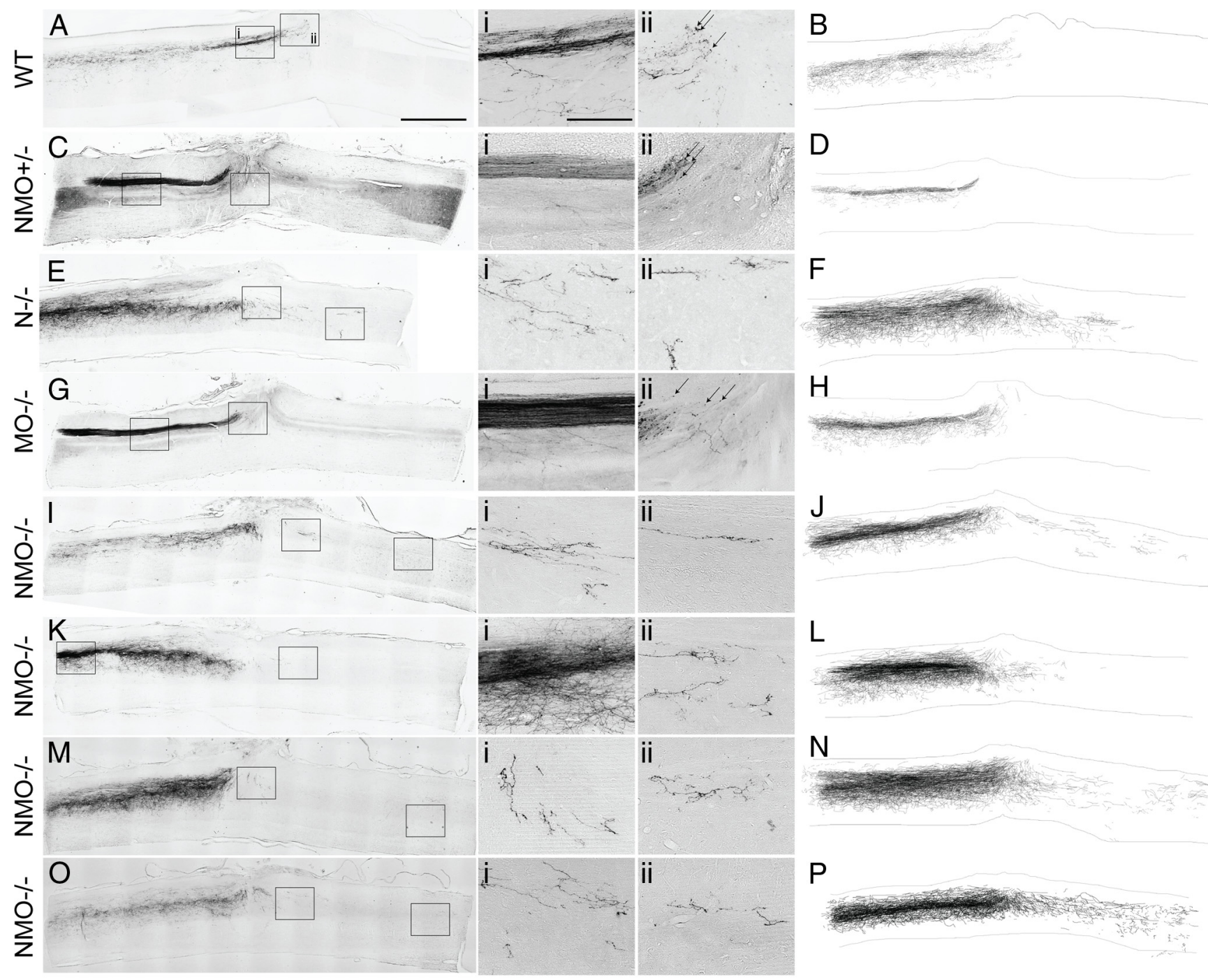

Q

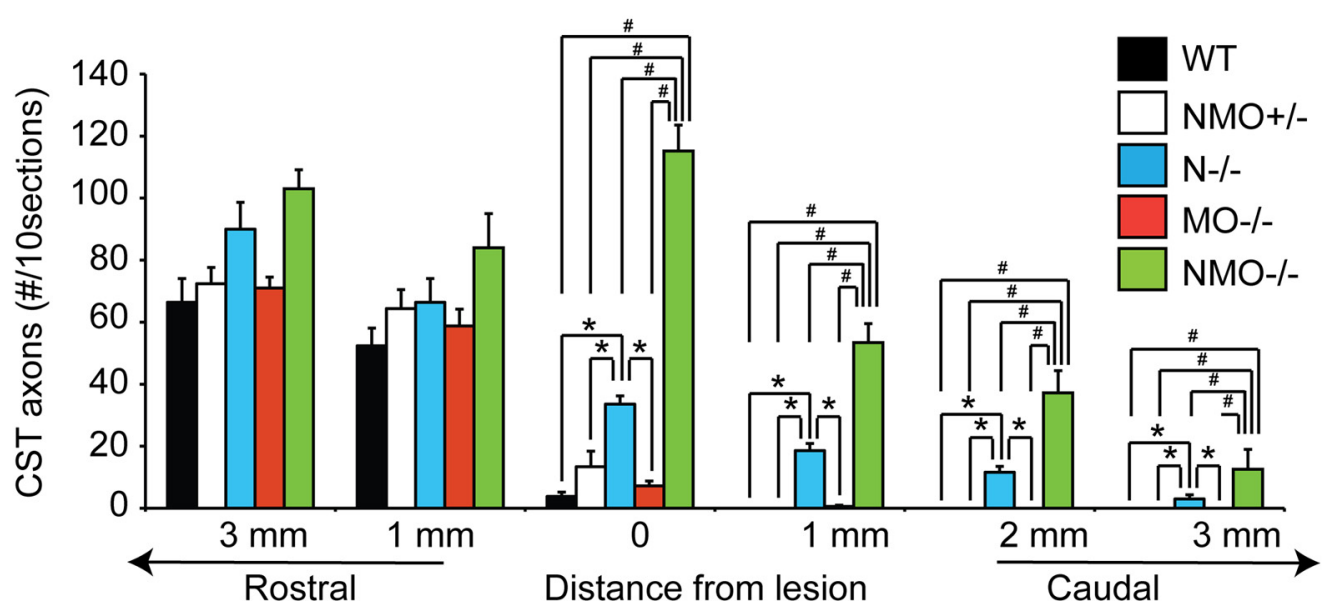

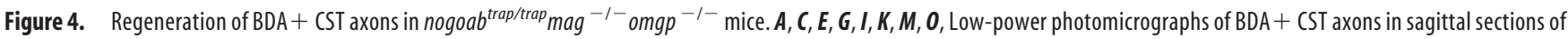

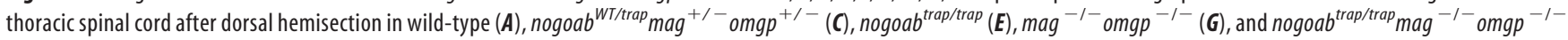
$(\boldsymbol{I}, \boldsymbol{K}, \boldsymbol{M}, \boldsymbol{O})$ mice, with finer detail shown in higher-power insets ( $\boldsymbol{i}$ and $\boldsymbol{i})$ for each image. Camera lucida of $10 \mathrm{BDA}+$ sagittal sections from each mouse were reconstructed and projected in a single image $(\boldsymbol{B}, \boldsymbol{D}, \boldsymbol{F}, \boldsymbol{H}, \boldsymbol{J}, \boldsymbol{L}, \boldsymbol{N}, \boldsymbol{P})$ to illustrate the extent of CST axon growth. $\boldsymbol{Q}$, Quantification of the number of BDA + CST axons 3 and $1 \mathrm{~mm}$ rostral to the lesion and $0,1,2$, and $3 \mathrm{~mm}$ caudal to the lesion. No significant difference in number of axons was observed between all genotypes of mice rostral to the lesion and between wild-type, nogoab $^{\text {WT/trap }} \mathrm{mag}^{+/-}$omgp $^{+/-}$, and $\mathrm{mag}^{-1-}$ omgp $^{-1-}$ mice caudal to the lesion. Nogoab ${ }^{\text {trap/trap }}$ displayed significantly more CST axons 0,1 , and $2 \mathrm{~mm}$ and caudal to the lesion site than wild-type, nogoab ${ }^{\text {WTtrap }}$ mag $^{+/-}$omgp $^{+/-}$, and $\mathrm{mag}^{-l-}$ omgp ${ }^{-l-}$ mice ${ }^{*} \mathrm{p}<0.01$, ANOVA). The nogoab ${ }^{\text {trap/trap }} \mathrm{mag}^{-1-} \mathrm{omgp}^{-1-}$ mice displayed significantly more BDA + CST axons at 0, 1, 2, and 3 mm caudal to the lesion site than wild-type,

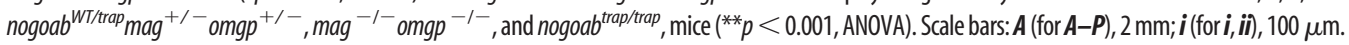



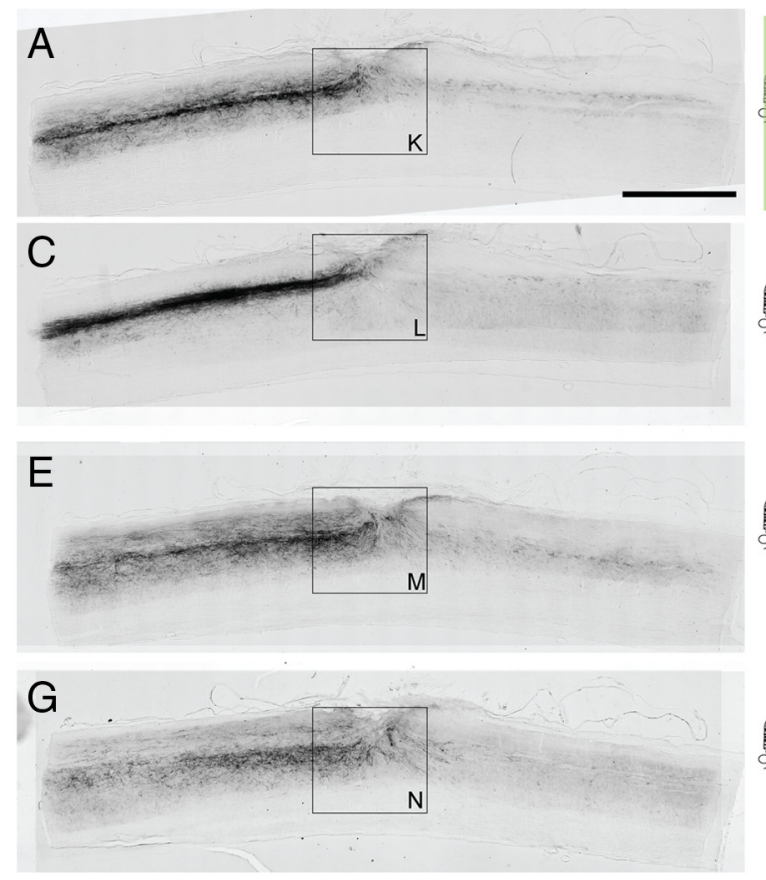

I

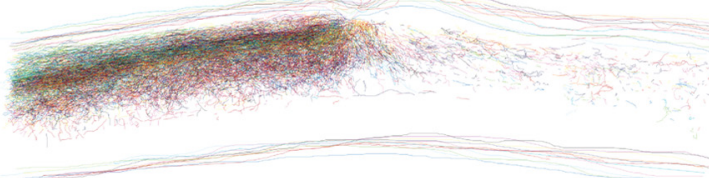

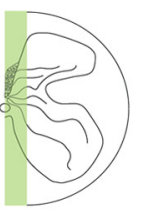
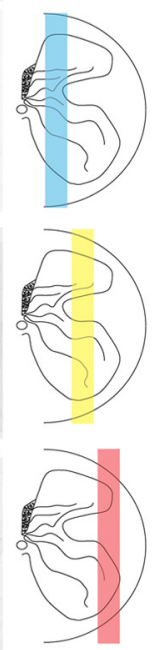

$\mathrm{H}$

F
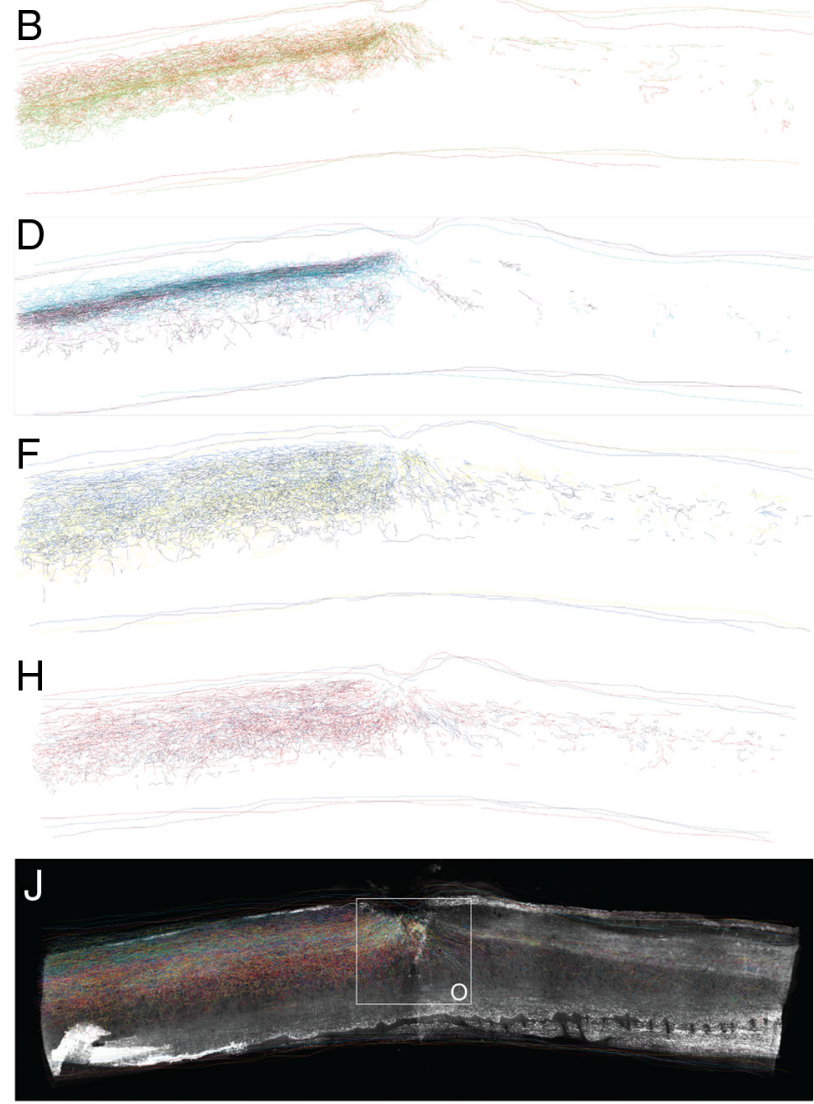
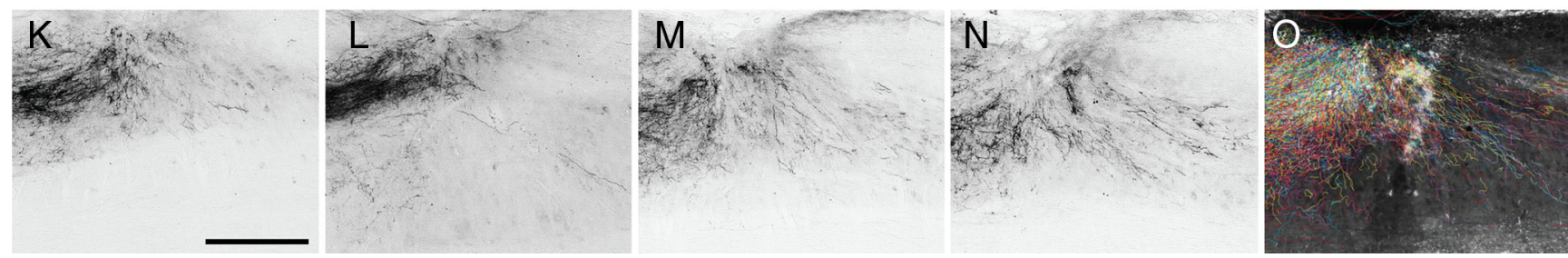

Figure 5. Regenerating CST axons preferentially grow in white matter in nogoab traptrap $\mathrm{mag}^{-1-}$ omgp ${ }^{-1-}$ mice. Low-power photomicrographs $(\boldsymbol{A}, \boldsymbol{C}, \boldsymbol{E}, \boldsymbol{G})$ illustrate composite projection

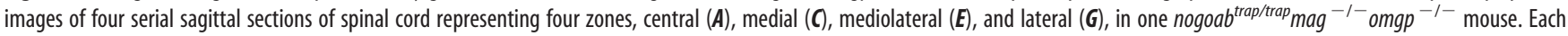
composite photomicrograph is recreated in camera lucida with an individual color depicting axons from each original sagittal section for the central $(\boldsymbol{B})$, medial $(\boldsymbol{D})$, mediolateral $(\boldsymbol{F})$, and lateral $(\boldsymbol{H})$ zones. $I$, Entire sagittal spinal camera lucida reconstruction. J, A composite projection image of four sections of spinal cord (1 from each zone) stained with GFAP-IR, with the entire camera lucida reconstruction layered on top. High-power photomicrographs show many axons growing around and through the lesion site in the central $(\boldsymbol{K})$, medial $(\boldsymbol{L})$, mediolateral $(\boldsymbol{M})$, and lateral $(\boldsymbol{N})$ zones. $\mathbf{0}$, Higher-power image of the entire camera lucida reconstruction merged with anti-GFAP staining (from $J$ ) shows the extent of the number of axons crossing into the caudal spinal cord. Scale bars: $\boldsymbol{A}($ for $\boldsymbol{A}-\boldsymbol{J}), 2 \mathrm{~mm} ; \boldsymbol{K}$ (for $\boldsymbol{K}-\mathbf{0}), 100 \mu \mathrm{m}$.

fibers in sagittal sections spanning a T8 dorsal hemisection (Fig. $4 A-P)$. The CST fails to grow caudal to the DhX in wild-type mice (Fig. 4A). CST axons are seen at the lesion perimeter, and most of these axons exhibit dystrophic end bulbs characteristic of abortive regeneration (Fig. 4 Aii, arrows) (Silver and Miller, 2004). Camera lucida reconstruction of serial sagittal sections through the lesion site illustrates the absence of BDA + CST axons caudal to the lesion (Fig. $4 B$ ) in wild-type mice after DhX, and the same phenotype was observed in nogoab ${ }^{W T / t r a p} \mathrm{mag}^{+/-}$omg $\mathrm{p}^{+/-}$mice (Fig. 4C,D) and $\mathrm{mag}^{-/-}$omg $\mathrm{p}^{-/-}$mice (Fig. 4G,H). Significant numbers of regenerating BDA + CST fibers were observed growing at 1,2 , and $3 \mathrm{~mm}$ past the lesion site in nogoab trap/trap (Fig. $4 E, F, Q)\left({ }^{*} p<0.01\right.$, ANOVA) and nogoab ${ }^{\text {trap } / \text { trap }}$ mag ${ }^{-/-}$ omgp ${ }^{-/-}$(Fig. 4I-P,Q) $\left(^{* *} p<0.01\right.$, ANOVA) mice in comparison to wild-type and nogoab ${ }^{\text {WT/trap }} \mathrm{mag}^{+/-}$omg $\mathrm{p}^{+/-}$mice. Furthermore, nogoab ${ }^{\text {trap } / \text { trap }} \mathrm{mag}^{-/-}$omgp $^{-/-}$mice displayed significantly more BDA + CST axons after DhX at 1, 2, and $3 \mathrm{~mm}$ caudal to the lesion site than nogoab ${ }^{\text {trap/trap }}$ mice (Fig. 4Q) ${ }^{* *} p<$ 0.001, ANOVA). High-power photomicrographs $i$ and $i$ illustrate the irregular growth patterns, characteristic (Steward et al., 2003) of regenerated fibers. The pattern of increased growth in the absence of Nogo increased by the absence of MAG and OMgp parallels the in vitro findings and rostral CST sprouting results.

\section{Regenerating CST axons preferentially grow in white matter caudal to the lesion}

We sought to ascertain whether regenerating fibers crossing the lesion in nogoab ${ }^{\text {trap/trap }} \mathrm{mag}^{-1-}$ omg $\mathrm{p}^{-/-}$mice preferentially grew in white or gray matter. We collected serial sections from a nogoab ${ }^{\text {trap/trap }}$ mag $^{-1-}$ omg $p^{-1-}$ mouse and reconstructed one side of the spinal cord using all sections with evidence of BDA+ axons (Fig. $5 A-J$ ). Photomicrographs $A, C, E$, and $G$ are projection images of four sagittal sections and represent four regions of spinal cord depicted in schematic. The green represents the cen- 


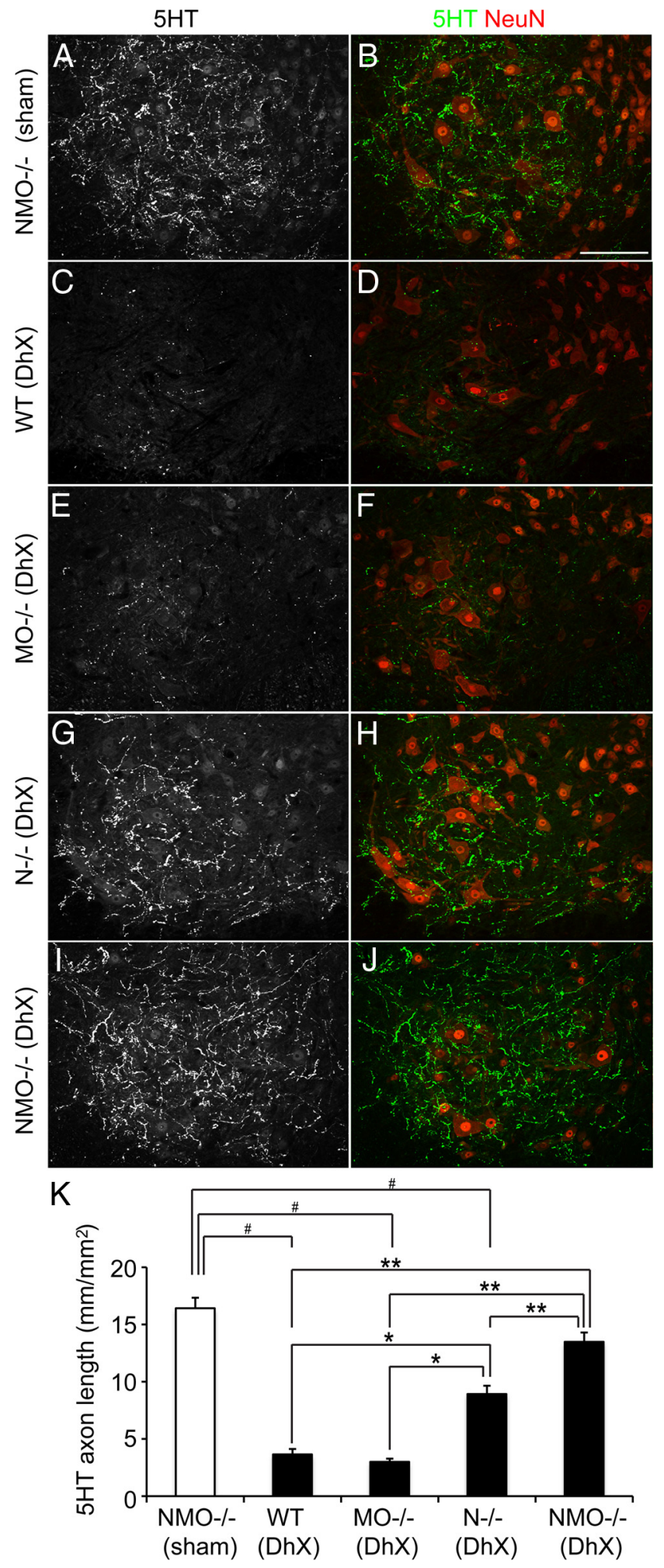

Figure 6. Regeneration of RST axons in nogoab $b^{\text {trap/trap }} \mathrm{mag}^{-/-}$omgp ${ }^{-1-}$ mice. Photomicrographs of L4 ventral spinal cord illustrate 5-HT-IR (white and green) and NeuN-IR (red) in sham-

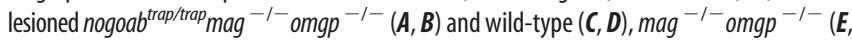
$\boldsymbol{F})$, nogoab ${ }^{\text {trap/trap }}(\boldsymbol{G}, \boldsymbol{H})$, and nogoab ${ }^{\text {trap/trap }} \mathrm{mag}^{-1-} \operatorname{omgp}^{-1-}(\boldsymbol{I}, \boldsymbol{J})$ mice after dorsal hemisection. Quantification of 5 -HT axon density $(\boldsymbol{K})$ reveals that DhX results in a significant reduction in serotonergic axon density in wild-type $(\boldsymbol{C}, \boldsymbol{D}), \mathrm{mag}^{-1-}$ omgp $^{-1-}(\boldsymbol{E}, \boldsymbol{F})$, and nogoab trap/trap $(\boldsymbol{G}, \boldsymbol{H})$ mice ( ${ }^{\#} p<0.001$, ANOVA) in comparison to sham-lesioned nogoab $^{\text {trap/trap }}$ mag $^{-1-}$ omgp ${ }^{-1-}$ mice $(\boldsymbol{A}, \boldsymbol{B})$. Significantly higher 5-HT axon density was tral zone (mostly dorsal and ventral column white matter and central canal), blue the medial zone (mostly dorsal and ventral gray matter), yellow the mediolateral zone (gray $>$ white matter), and red the lateral zone (gray $<$ white mater). Camera lucida reconstructions $B, D, F$, and $H$ represent each of the collapsed images in the projection in a distinct color. Most axons caudal to the lesion site appear in zones with a greater percentage of white matter. The percentage of BDA + CST axons observed in white matter $2 \mathrm{~mm}$ caudal to the lesion site in nogoab $b^{\text {trap } / \text { trap }} \mathrm{mag}^{-/-}$ omgp ${ }^{-/-}$mice is $62.1 \pm 1.4 \%(n=9, \pm \mathrm{SEM})$.

To confirm that the large number of axons present at and past the lesion site (Fig. $5 K, L$ ) reflect regenerative growth, we immunostained sagittal sections of spinal cord from each of the four zones with GFAP to observe the extent of injury-induced astrocyte activation (see below). The GFAP-IR images were projected onto the camera lucida reconstruction of axonal growth (Fig. 5I) to demarcate the lesion site relative to regenerating axons (Fig $5 J)$. GFAP-IR can be seen extending from the dorsal surface of the spinal cord to below the central canal (Fig. $5 \mathrm{~J}, \mathrm{O}$ ). Thus, reconstruction demonstrates that CST fibers regenerate extensively into white matter greater than gray matter in the caudal spinal cord of nogoab ${ }^{\text {trap/trap }} \mathrm{mag}^{-/-}$omgp ${ }^{-/-}$mice.

\section{Raphespinal regeneration after dorsal hemisection in nogoab ${ }^{\text {trap/trap }}$ mag $^{-/-}$omg $^{-/-}$mice}

The DhX injury damages multiple spinal tracts in addition to the CST, including the serotonergic raphespinal tract (RST). The RST contributes significantly to locomotion (Lemon, 2008). To determine whether the growth of raphespinal axons is differentially sensitive to the presence of Nogo-A/B, MAG, and OMgp, we assessed the growth pattern of the RST after DhX in wild-type, nogoab ${ }^{\text {trap/trap }}, \mathrm{mag}^{-/-}$omg $\mathrm{p}^{-/-}$, and nogoab ${ }^{\text {trap/trap }}$ $\mathrm{mag}^{-/-}$omgp ${ }^{-/-}$mice. 5-HT-immunoreactive (5-HT-IR) RST axons originating in the brainstem descend bilaterally in the lateral columns and densely innervate both dorsal and ventral gray matter at all spinal levels. We focused our analysis on the ventral horn of the lumbar spinal cord, where the RST is known to synapse on motor neurons (Mason, 2001). 5-HT-IR axons are observed to ramify densely in the L4/5 ventral horn of shamlesioned wild-type and nogoab trap/trap $\mathrm{mag}^{-/-}$omg $p^{-1-}$ mice (Fig. 6A,B). DhX at T8 significantly reduces the density of 5 -HT-IR by $75 \%$ in wild-type (Fig. $6 C, D, K)\left({ }^{*} p<0.001\right.$, ANOVA) and $m a g^{-/-} o m g p^{-/-}$(Fig. $\left.6 E, F, K\right)\left({ }^{*} p<0.001\right.$, ANOVA) mice. The reduction of caudal 5-HT fibers is less pronounced in nogoab ${ }^{\text {trap/trap }}$ mice (Fig. $\left.6 G, H, K\right)\left({ }^{*} p<0.001\right.$, ANOVA). In obvious distinction, the density of 5-HT innervation in the L4/5 ventral horn of nogoab ${ }^{\text {trap/trap }} \mathrm{mag}^{-/-}$omgp ${ }^{-/-}$mice is restored fully, being insignificantly different from shamlesioned wild-type or nogoab trap/trap $\mathrm{mag}^{-/-}$omg $\mathrm{p}^{-/-}$control mice (Fig. 6I-K). The intact RST innervation likely reflects caudal sprouting of these fibers after the injury to restore normal fiber density. As for other measures, there is no regenerative phenotype in $m a g^{-/-} o m g p^{-/-}$mice, but the partial phenotype in the nogoab trap/trap mice is enhanced by deletion of MAG and OMgp.

observed in nogoab trap/trap $(\boldsymbol{G}, \boldsymbol{H})$ mice after DhX than in wild-type $(\boldsymbol{C}, \boldsymbol{D})$ and $\mathrm{mag}^{-1-}$ $\operatorname{omgp}^{-l-}(\boldsymbol{E}, \boldsymbol{F})$ mice ${ }^{*} p<0.001$, ANOVA). Significantly higher 5-HT axon density was observed in nogoab trap/trap $\mathrm{mag}^{-1-}$ omgp ${ }^{-1-}$ mice after dorsal hemisection than in wild-type $(\boldsymbol{C}, \boldsymbol{D}), \mathrm{mag}^{-/-}$omgp $^{-\prime-}(\boldsymbol{E}, \boldsymbol{F})$, and nogoab ${ }^{\text {trap/trap }}(\boldsymbol{G}, \boldsymbol{H})$ mice $\left({ }^{* *} p<0.001\right.$, ANOVA). There was no significant difference in $5-\mathrm{HT}$ axon density between intact $(\boldsymbol{A}, \boldsymbol{B})$ and lesioned $(\boldsymbol{I}$, J) nogoab ${ }^{\text {trap/trap }} \mathrm{mag}^{-/-}$omgp $^{-/-}$mice (K). Scale bar (in B): $50 \mu \mathrm{m}$. 


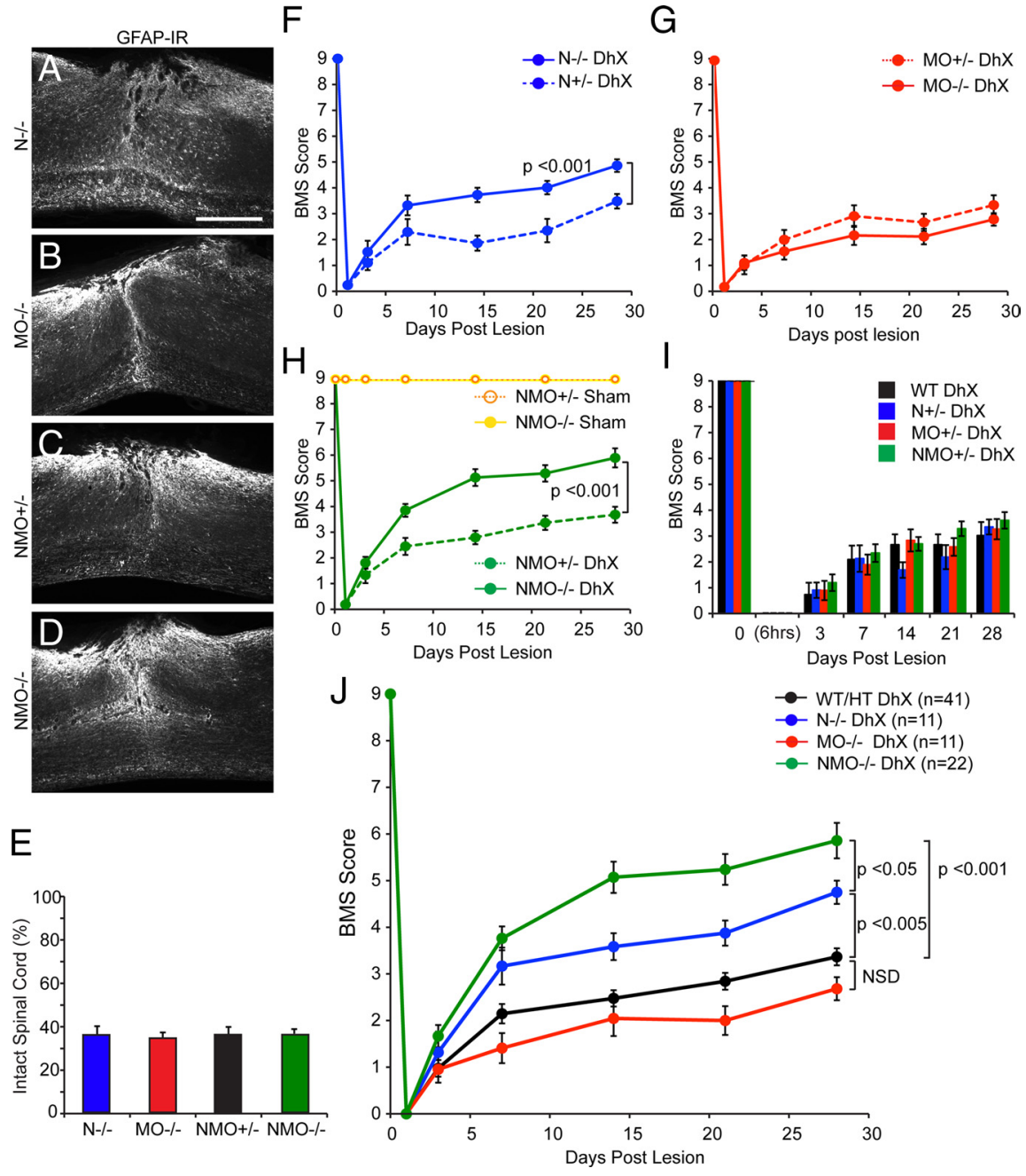

Figure 7. Improved locomotor recovery in mice lacking Nogo-A/B after DhX. Photomicrographs of sagittal sections of thoracic spinal cord immunostained for GFAP in nogoab ${ }^{\text {trap/trap }}(\boldsymbol{A}), \mathrm{mag}^{-/-}$omgp $^{-1-}(\boldsymbol{B})$, nogoab $^{\text {wt/trap }} \mathrm{mag}^{+/-}$omgp $^{+/-}(\boldsymbol{C})$, and nogoab ${ }^{\text {trap/trap }} \mathrm{mag}^{-/-}$omgp $^{-/-}$(D) mice after DhX. Quantification of GFAP-negative spared tissue is equivalent between genotypes after DhX (E). All mice were behaviorally assessed using the BMS $(\boldsymbol{F}-\boldsymbol{J})$; nogoab ${ }^{\text {trap/trap }}(n=11$, blue line) recovered significant hindlimb function in comparison to nogoab ${ }^{W T / \text { trap }}$ mice $(n=9$, stippled blue line, repeated-measures ANOVA, $p<$ $0.001, F)$. There was no significant functional recovery in $\mathrm{mag}^{-/-} \mathrm{omgp}^{-/-}\left(n=12\right.$, red line) in comparison to mag $\mathrm{g}^{+/-}$ $\mathrm{omgp}^{+\prime-}$ control mice $\left(n=8\right.$, stippled red line, G). nogoab trap/trap $\mathrm{mag}^{-/-} \mathrm{omgp}^{-/-}(n=22$, green line) recovered significant function in comparison to nogoab ${ }^{W T / t r a p} \mathrm{mag}^{+/-}$omgp $^{+/-}$control lesioned mice (green stippled line, repeated-measures ANOVA, $p<0.001, \boldsymbol{H})$. There was no significant difference in BMS scores between heterozygote mice at any behavioral time point $(\boldsymbol{I})$; therefore, these groups were combined for comparison with behavioral scores of single, double, and triple mutants (WT/HT group, $\boldsymbol{J})$. Repeated-measures ANOVA revealed that there was no significant difference in behavioral recovery between WT/HT (blackline) and mag $^{-1-}$ omgp $^{-1-}$ (red line) mice; however, both nogoab ${ }^{\text {trap/trap }}$ (blue line, $p<0.005$ ) and

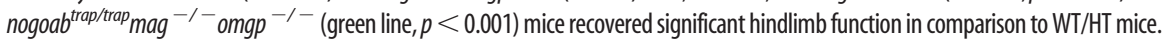
Furthermore nogoab ${ }^{\text {trap/trap }} \mathrm{mag}^{-1-}$ omgp $^{-{ }^{-1-}}$ recovered significantly more hindlimb function than nogoab trap/trap $(p<0.05)$. Scale bar, $500 \mu \mathrm{m}$.

\section{Locomotor recovery in nogoab ${ }^{\text {trap/trap }} \mathrm{mag}^{-/-} \mathrm{omgp}^{-/-}$mice after SCI}

The primary outcome in this study is the degree of axonal growth after spinal lesion in mice of different genotypes. However, we also scored functional outcomes by observing locomotion in the open field for each cohort. Standardizing lesion severity in experimental SCI models is crucial to correlating anatomical with functional outcomes. Therefore, we assessed lesion depth in animals that underwent dorsal hemisection (Fig. $7 A-D$ ), using GFAP immunoreactivity. Wild-type, nogoab ${ }^{\text {trap/trap }}$ (Fig. 7A), $\mathrm{mag}^{-/-}$omgp ${ }^{-/-}$(Fig. 7B), nogoab ${ }^{\text {WT/trap }}$ mag $^{+/-}$omgp $^{+/-}$(Fig. $7 C)$, and nogoab ${ }^{\text {WT/trap }} \mathrm{mag}^{+/-}$omg $^{+/-}$nogoab trap/trap $^{\text {mag }}{ }^{-1-}$ omgp ${ }^{-/-}$(Fig. 7D) mice display equivalent induction of GFAP at the lesion site 5 weeks after lesion. The percentage of GFAP-negative spared spinal tissue in the remaining groups of animals is insignificantly different between genotypes (Fig. 7E).

Mice behavior was assessed on day 3 before lesion, and $6 \mathrm{~h}$ and 3, 7, 14, 21, and $28 \mathrm{~d}$ after lesion (Fig. 7F-J). All animals display flaccid hindlimb paralysis $6 \mathrm{~h}$ after lesion and slowly regain function over the observation period. Only nogoab ${ }^{\text {trap/trap }}$ and nogoab trap/trap $_{\mathrm{mag}^{-1-}}$ omg $\mathrm{p}^{-1-}$ mice recovered significant hindlimb function in comparison to nogoab ${ }^{w t / t r a p}$ (Fig. $7 F$ ) (repeated-measures ANOVA, $p<0.001$ ) and nogoab ${ }^{\text {wt/trap }} \mathrm{mag}^{+/-}$omg p $^{+/-}$(Fig. $7 H$ ) (repeated-measures ANOVA, $p<$ 0.001 ) control mice; $\mathrm{mag}^{-/-}$omg $\mathrm{p}^{-/-}$ mice failed to recover significant function in comparison to $\mathrm{mag}^{+/-}$omg $\mathrm{p}^{+/-}$mice (Fig. $7 G$ ). There was no significant difference in BMS scores between wild-type, nogoab wt/trap $\mathrm{mag}^{+/-}$omgp ${ }^{+/-}$, and nogoab $^{\text {wt/trap }}$ mag $^{+/-}$omg $p^{+/-}$control mice after DhX (Fig. 7I). Therefore we pooled the control groups (Fig. 7J) (WT/HT) for comparison to single, double, and triple mutants. Both nogoab trap/trap and nogoab ${ }^{\text {trap/trap }} \mathrm{mag}^{-/-}$omg $\mathrm{p}^{-/-}$mice recovered significant function in comparison to controls (Fig. 7J) (repeated-measures ANOVA, $p<0.005$ and $p<0.001$, respectively). Furthermore nogoab ${ }^{\text {trap/trap }} \mathrm{mag}^{-/-}$ $o m g p^{-/-}$mice recovered to a greater degree than do nogoab ${ }^{\text {trap/trap }}$ mice (repeated-measures ANOVA, $p<0.05$ ). There was no significant difference between $\mathrm{mag}^{-/-}$omg $\mathrm{p}^{-/-}$and control mice.

To support the robustness of this finding across injury severity, we examined a separate cohort of nogoab trap/trap $\mathrm{mag}^{-/-}$omg $\mathrm{p}^{-/-}$and nogoab ${ }^{\text {WT/trap }} \mathrm{mag}^{+/-}$ omg $p^{+/-}$that had a more severe, neartotal transection lesion due to deeper cutting at the time of surgery. Such mice preserve $<10 \%$ of tissue (Fig. $8 A-D$ ). The severely injured nogoab ${ }^{\text {trap } / \text { trap }} \mathrm{mag}^{-1-}$ $o m g p^{-1-}$ mice recover greater function in the open field than do the nogoab ${ }^{W T / t r a p}$ $\mathrm{mag}^{+/-}$omg $\mathrm{p}^{+/-}$mice (Fig. 8E) (repeated-measures ANOVA, $p<$ $0.001)$.

\section{Discussion}

The major conclusions from this work are that Nogo-A is the myelin inhibitor with the greatest inhibitory activity, and that MAG and OMgp play synergistic roles in preventing axonal growth in the adult mammalian CNS. These conclusions are supported by analysis of axonal outgrowth in vitro on substrates coated with myelin prepared from mice of various mutant genotypes. The MAG/OMgp mutant myelin is as inhibitory as wildtype myelin. The reduced inhibition generated by deletion of 

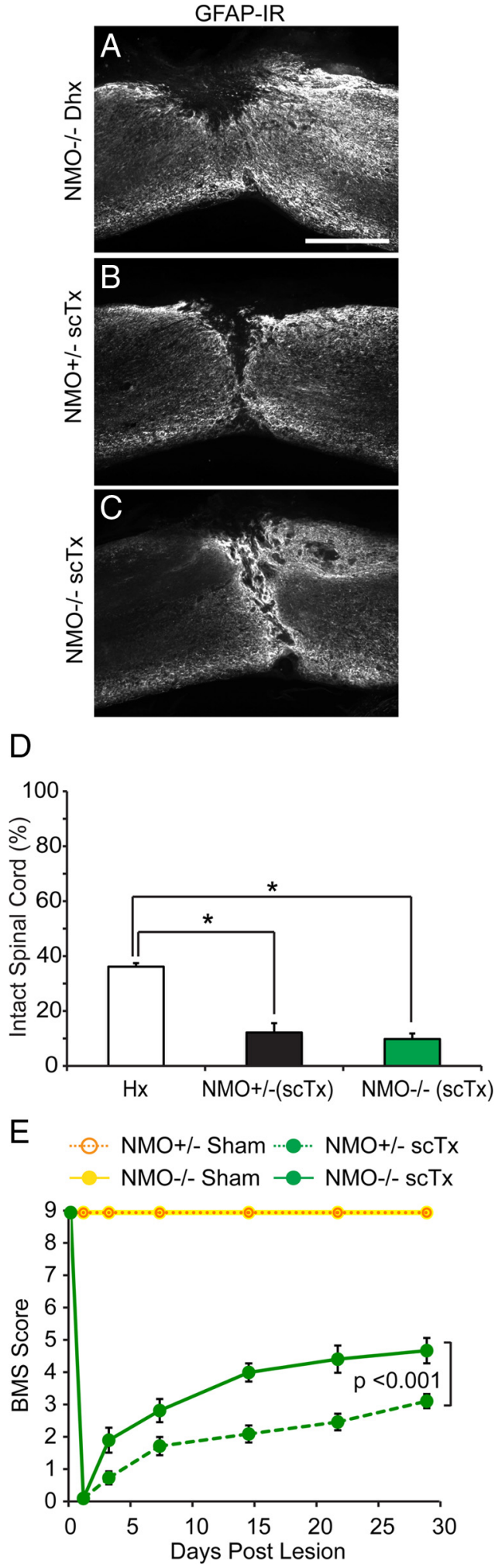

Figure 8. Improved locomotor recovery in mice lacking Nogo-A/B after subcomplete transection. Photomicrographs of sagittal sections of thoracic spinal cord immunostained for GFAP in nogoab trap/trap $_{\text {mag }^{-1-} \text { omgp }^{-1-} \text { after dorsal hemisection }(\boldsymbol{A}) \text { and nogoab }}^{\text {wttrap }} \mathrm{mag}^{+/-}$ omgp $^{+/-}(\boldsymbol{B})$ and nogoab trap/trap $\mathrm{mag}^{-1-}$ omgp $^{-1-}(\boldsymbol{C})$ mice after subcomplete transection (scTx). D, Quantification of GFAP-negative spared tissue is significantly less in nogoab ${ }^{\text {wt/trap }} \mathrm{mag}^{+/-}$ $\mathrm{omgp}^{+/-}$and nogoab ${ }^{\text {trap/trap }} \mathrm{mag}^{-1-}$ omgp ${ }^{-1-}$ mice after scTx than after hemisection ${ }^{*} p<$ 0.001 , ANOVA). $\boldsymbol{E}$, There was no significant difference between nogoab ${ }^{\text {wt/trap }}$ mag $^{+/-}$omgp $^{+/-}$ and nogoab trap/trap $\mathrm{mag}^{-1-}$ omgp $^{-1-}$ mice after scTx. nogoab ${ }^{\text {trap/trap }} \mathrm{mag}^{-1-}$ omgp $^{-1-}$ mice recovered significant hindlimb function in comparison to nogoab ${ }^{\text {wttrap }} \mathrm{mag}^{+/-}$omgp $^{+/-}$after scTx (repeated-measures ANOVA, $p<0.001$ ). Scale bar, $500 \mu \mathrm{m}$.
Nogo-A is enhanced by deletion of MAG/OMgp as well. A similar synergy of MAG plus OMgp with Nogo-A is observed in spinal cord-injured mice through examination of rostral CST sprouting, CST regeneration across the lesion, caudal RST sprouting, and locomotor recovery. We conclude that Nogo-A is a principal myelin inhibitor, with a redundant and synergistic role for MAG plus OMgp.

\section{Relative inhibitory activity of CNS myelin components}

The myelin extracted from $\mathrm{mag}^{-/-} \mathrm{omgp} \mathrm{p}^{-/-}$mice is as inhibitory as wild-type myelin in neurite outgrowth from wild-type DRG neurons. We chose to use sensory neurons as they express NgR1 (Fournier et al., 2001), NgR2 (Venkatesh et al., 2005), Lingo-1 (Mi et al., 2004), p75 (McMahon et al., 1994), TAJ/ TROY (Park et al., 2005; Shao et al., 2005), and PirB (Atwal et al., 2008), all the receptor components that have been reported necessary to transduce Nogo-A, MAG, and OMgp binding. The lack of significant disinhibition observed on myelin from $\mathrm{mag}^{-1-}$ omg $p^{-/-}$mice may be due to our extraction protocol, which may have failed to collect the axogliasome OMgp-rich fraction (Huang et al., 2005). However, previous studies have also reported a lack of enhanced neurite outgrowth of DRG cells grown on $1 \mu \mathrm{g}$ of extracted myelin from $\mathrm{mag}^{-1-}$ (Bartsch et al., 1995; $\mathrm{Ng}$ et al., 1996) and $o m g p^{-/-}$(Ji et al., 2008) mice. Both of these studies concluded that other inhibitors present in CNS myelin mask the potential benefit that removing either one of these two proteins would otherwise show. Accordingly, we compared the outgrowth-inhibitory activity of myelin from nogoab ${ }^{\text {trap/trap }}$ and nogoab ${ }^{\text {trap/trap }} \mathrm{mag}^{-/-}$omgp ${ }^{-/-}$mice. As previously reported (Kim et al., 2003; Simonen et al., 2003; Zheng et al., 2003), we find that myelin extracted from nogoab ${ }^{-/-}$mice was less inhibitory to neurite outgrowth than myelin from wild-type mice. Critically, we find that nogoab trap/trap $\mathrm{mag}^{-/-}$omg ${ }^{-/-}$myelin is less inhibitory than nogoab ${ }^{\text {trap/trap }}$ myelin. In fact, there is no detectable inhibition of axonal growth by nogoab ${ }^{\text {trap/trap }} \mathrm{mag}^{-/-}$omgp $\mathrm{p}^{-1-}$ myelin. It should be noted that we used a detergent extraction protocol for isolating myelin. This may explain why there is no remaining inhibition from other proteins reported to be associated with crude myelin, such as ephrinB3 (Benson et al., 2005) and netrin-1 (Löw et al., 2008). Under these assay conditions, Nogo-A, MAG, and OMgp fully account for CNS myelin inhibition of axonal outgrowth.

\section{Enhanced sprouting and regeneration of lesioned CST and RST in vivo}

In accord with previous reports for single $\mathrm{mag}^{-/-}$(Bartsch et al., 1995) and $o m g p^{-1-}$ (Ji et al., 2008) mice, we fail to observe growth of CST axons above the lesion, or of CST plus RST axons below the lesion after dorsal hemisection in wild-type or $\mathrm{mag}^{-1-}$ omgp ${ }^{-/-}$mice. In line with our previous data, we find that nogo$a b^{\text {trap/trap }}$ mice display a significantly greater number of CST axons sprouting above the lesion and regenerating past the lesion (Kim et al., 2003; Cafferty et al., 2007a), as well as enhanced RST innervation of the lumbar ventral horn. Most importantly, these phenotypes are augmented in nogoab ${ }^{\text {trap/trap }} \mathrm{mag}^{-1-}$ omgp ${ }^{-1-}$ mice. Thus, the in vivo anatomical outcome from SCI exactly parallels the in vitro axonal outgrowth results with regard to the relative roles of Nogo-A, MAG, and OMgp.

Although the primary focus of these studies was axonal outgrowth inhibition by myelin, we also monitored BMS scores as a neurological outcome after SCI. As in the axonal assays, the $m a g^{-/-}$omg $p^{-/-}$mice behave indistinguishably from wild-type or heterozygous controls. Despite this lack of direct effect, MAG 
and OMgp expression play a role in the recovery in mice lacking Nogo-A expression. Recovery is significantly greater when all three NgR1/PirB ligands are absent. The recovery of the triplemutant mice is dramatically improved compared to control mice, reaching a BMS score of $5.9 \pm 0.4$ versus $3.4 \pm 0.2$.

Striking axonal growth in nogoab ${ }^{\text {trap/trap }} \mathrm{mag}^{-1-}$ omgp $\mathrm{p}^{-1-}$ mice includes the sprouting of rostral CST fibers and caudal RST fibers. These zones are largely intact and devoid of gliotic reaction. The sprouting phenotypes are similar to the pyramidotomyinduced CST sprouting observed in $n g r 1^{-1-}$ and nogoa $a^{\text {atg/atg }}$ mice (Cafferty and Strittmatter, 2006). The zone of overt of glial scarring at the lesion site shows regenerative growth, although this is less prolific than the axonal sprouting far from the lesion. The greater degree of plasticity-linked sprouting than frank regeneration is consistent with the deletion of myelin inhibitors not altering the inhibitory extracellular matrix enriched at the lesion site (for review, see Busch and Silver, 2007). Furthermore, many other inhibitory proteins that were not targeted in this study remain in nogoab $b^{\text {trap } / \text { trap }} \mathrm{mag}^{-1-}$ omg $p^{-1-}$ mice, including ephrinB3 (Benson et al., 2005), netrin-1 (Löw et al., 2008), SEMA6A (Rünker et al., 2008), SEMA4D (Moreau-Fauvarque et al., 2003), and RGMa (Hata et al., 2006).

\section{Other physiological functions for MAG and OMgp}

Previous evaluation of $m a g^{-/-}$and $o m g p^{-/-}$mice has identified important roles for these proteins separate from function as inhibitors of neurite outgrowth. MAG is crucial for the initiation and maintenance of myelination in the CNS. Consistent with MAG localization to paranodal regions, ultrastructural analysis

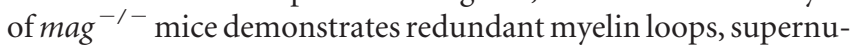
merary myelin sheaths, and disorganization of the axoglial junctions in the paranodal regions (for review, see Bartsch, 1996). Signaling downstream of MAG in oligodendrocytes may require specific splice forms of the MAG cytoplasmic tail and Fyn activation (Fujita et al., 1998; Biffiger et al., 2000).

OMgp was originally identified as being enriched in CNS white matter (Vourc'h and Andres, 2004), and is expressed by both oligodendrocytes and neurons (Huang et al., 2005). OMgp has been shown to have an anti-proliferative effect when overexpressed in NIH3T3 cells (Habib et al., 1998) via a PDGFdependent mechanism. PDGF is a known oligodendrocyte precursor cell (OPC) mitogen (Wolswijk et al., 1991); hence, OMgp could determine OPC proliferation and subsequent differentiation. A recent study has also implicated OMgp in maintaining the stability of node of Ranvier, where it additionally may restrict aberrant axonal sprouting (Huang et al., 2005).

Nogo-A has also been reported to play a role in the developmental timing of myelination (Pernet et al., 2008). Despite these varied myelin phenotypes for Nogo, MAG, and OMgp, there is no overt deficit at the light microscopy level in myelination or oligodendrocytes in adult triple-mutant mice. Thus, these roles in myelin formation are unlikely to occur via shared synergistic mechanisms. Consistent with independent roles for these three proteins in myelination, no myelin phenotype has been reported for NgR1-null mice.

\section{Implications for spinal cord injury therapy}

In light of the data presented here and the mild axon regenerative phenotype observed in both $m a g^{-1-}$ and $o m g p^{-1-}$ mice, it is clear that Nogo-A is the most potent NgR1/PirB ligand expressed in the adult spinal cord. Indeed, targeting Nogo-A pharmacologically (Schnell and Schwab, 1990, 1993; Bregman et al., 1995; Brösamle et al., 2000; Liebscher et al., 2005) has been shown to enhance axonal regeneration and functional recovery after SCI in rodents. Genetic evidence to support the fact that Nogo-A is a key inhibitor of axonal regeneration has been less consistent; some studies report significant axonal growth after SCI in nogo ${ }^{-1-}$ mice (Kim et al., 2003; Simonen et al., 2003; Dimou et al., 2006), while others fail to observe this phenotype (Zheng et al., 2003; Lee et al., 2009). While there may be uncertainty regarding the variables influencing the phenotypes of various nogo ${ }^{-1-}$ mice, such as the age of lesioned mice, background strain of mice, and nature of the mutant allele (Cafferty and Strittmatter, 2006; Dimou et al., 2006; Cafferty et al., 2007a; Steward et al., 2007), the efficacy of anti-Nogo-A therapies has been reported in nonhuman primate SCI models (Freund et al., 2006, 2007, 2009; Beaud et al., 2008) and is being tested now in the clinic.

While the current studies do not support separate targeting of either MAG or OMgp as a means to promote neurological recovery, they do demonstrate a clear benefit in all assays for targeting the three myelin ligands as a group rather than simply targeting Nogo-A alone. The molecular basis for this synergy is likely the shared receptors, NgR1 and PirB. The only published method for targeting all three ligands is the NgR1 decoy receptor (Fournier et al., 2002; Li et al., 2004, 2005). Of note, the degree of CST axonal growth and neurological benefit observed after NgR(310)ecto-Fc treatment of dorsal hemisected rats was greater than with antiNogo antibody treatment (Li et al., 2004; Liebscher et al., 2005). Although these two studies were conducted in different laboratories, the results parallel those observed in the Nogo-A, MAG, OMgp triple mutant as compared to the Nogo-A single-mutant mouse studies here. The greater benefit of targeting all three ligands may also explain the benefit of $\mathrm{NgR}(310)$ ecto-Fc treatment for spinal contusion recovery (Wang et al., 2006) in the absence of any report of benefit for anti-Nogo treatment of spinal contusion injury.

We conclude that combined targeting of NgR1/PirB ligands promotes axonal regeneration and functional recovery to a certain point. Surmounting this threshold will require targeting additional inhibitory proteins present in CNS, while concomitantly addressing the low intrinsic growth capacity of CNS neurons.

\section{References}

Atwal JK, Pinkston-Gosse J, Syken J, Stawicki S, Wu Y, Shatz C, TessierLavigne M (2008) PirB is a functional receptor for myelin inhibitors of axonal regeneration. Science 322:967-970.

Barton WA, Liu BP, Tzvetkova D, Jeffrey PD, Fournier AE, Sah D, Cate R, Strittmatter SM, Nikolov DB (2003) Structure and axon outgrowth inhibitor binding of the Nogo-66 receptor and related proteins. EMBO J 22:3291-3302.

Bartsch U (1996) Myelination and axonal regeneration in the central nervous system of mice deficient in the myelin-associated glycoprotein. J Neurocytol 25:303-313.

Bartsch U, Bandtlow CE, Schnell L, Bartsch S, Spillmann AA, Rubin BP, Hillenbrand R, Montag D, Schwab ME, Schachner M (1995) Lack of evidence that myelin-associated glycoprotein is a major inhibitor of axonal regeneration in the CNS. Neuron 15:1375-1381.

Basso DM, Fisher LC, Anderson AJ, Jakeman LB, McTigue DM, Popovich PG (2006) Basso Mouse Scale for Locomotion detects differences in recovery after spinal cord injury in five common mouse strains. J Neurotrauma 23:635-659.

Beaud ML, Schmidlin E, Wannier T, Freund P, Bloch J, Mir A, Schwab ME, Rouiller EM (2008) Anti-Nogo-A antibody treatment does not prevent cell body shrinkage in the motor cortex in adult monkeys subjected to unilateral cervical cord lesion. BMC Neurosci 9:5.

Benson MD, Romero MI, Lush ME, Lu QR, Henkemeyer M, Parada LF (2005) Ephrin-B3 is a myelin-based inhibitor of neurite outgrowth. Proc Natl Acad Sci U S A 102:10694-10699.

Biffiger K, Bartsch S, Montag D, Aguzzi A, Schachner M, Bartsch U (2000) Se- 
vere hypomyelination of the murine $\mathrm{CNS}$ in the absence of myelin-associated glycoprotein and fyn tyrosine kinase. J Neurosci 20:7430-7437.

Bregman BS, Kunkel-Bagden E, Schnell L, Dai HN, Gao D, Schwab ME (1995) Recovery from spinal cord injury mediated by antibodies to neurite growth inhibitors. Nature 378:498-501.

Brösamle C, Huber AB, Fiedler M, Skerra A, Schwab ME (2000) Regeneration of lesioned corticospinal tract fibers in the adult rat induced by a recombinant, humanized IN-1 antibody fragment. J Neurosci 20:80618068.

Bulsara KR, Iskandar BJ, Villavicencio AT, Skene JH (2002) A new millenium for spinal cord regeneration: growth-associated genes. Spine (Phila Pa 1976) 27:1946-1949.

Busch SA, Silver J (2007) The role of extracellular matrix in CNS regeneration. Curr Opin Neurobiol 17:120-127.

Cafferty WB, Strittmatter SM (2006) The Nogo-Nogo receptor pathway limits a spectrum of adult CNS axonal growth. J Neurosci 26:1224212250.

Cafferty WB, Kim JE, Lee JK, Strittmatter SM (2007a) Response to correspondence: Kim et al., "Axon regeneration in young adult mice lacking Nogo-A/B.” Neuron 38, 187-199. Neuron 54:195-199.

Cafferty WB, Yang SH, Duffy PJ, Li S, Strittmatter SM (2007b) Functional axonal regeneration through astrocytic scar genetically modified to digest chondroitin sulfate proteoglycans. J Neurosci 27:2176-2185.

Chen MS, Huber AB, van der Haar ME, Frank M, Schnell L, Spillmann AA, Christ F, Schwab ME (2000) Nogo-A is a myelin-associated neurite outgrowth inhibitor and an antigen for monoclonal antibody IN-1. Nature 403:434-439.

Dimou L, Schnell L, Montani L, Duncan C, Simonen M, Schneider R, Liebscher T, Gullo M, Schwab ME (2006) Nogo-A-deficient mice reveal strain-dependent differences in axonal regeneration. J Neurosci 26:5591-5603.

Domeniconi M, Cao Z, Spencer T, Sivasankaran R, Wang K, Nikulina E, Kimura N, Cai H, Deng K, Gao Y, He Z, Filbin M (2002) Myelinassociated glycoprotein interacts with the Nogo66 receptor to inhibit neurite outgrowth. Neuron 35:283-290.

Fournier AE, GrandPre T, Strittmatter SM (2001) Identification of a receptor mediating Nogo-66 inhibition of axonal regeneration. Nature 409:341-346.

Fournier AE, Gould GC, Liu BP, Strittmatter SM (2002) Truncated soluble Nogo receptor binds Nogo-66 and blocks inhibition of axon growth by myelin. J Neurosci 22:8876-8883.

Freund P, Schmidlin E, Wannier T, Bloch J, Mir A, Schwab ME, Rouiller EM (2006) Nogo-A-specific antibody treatment enhances sprouting and functional recovery after cervical lesion in adult primates. Nat Med 12:790-792.

Freund P, Wannier T, Schmidlin E, Bloch J, Mir A, Schwab ME, Rouiller EM (2007) Anti-Nogo-A antibody treatment enhances sprouting of corticospinal axons rostral to a unilateral cervical spinal cord lesion in adult macaque monkey. J Comp Neurol 502:644-659.

Freund P, Schmidlin E, Wannier T, Bloch J, Mir A, Schwab ME, Rouiller EM (2009) Anti-Nogo-A antibody treatment promotes recovery of manual dexterity after unilateral cervical lesion in adult primates-reexamination and extension of behavioral data. Eur J Neurosci 29:983-996.

Fujita N, Kemper A, Dupree J, Nakayasu H, Bartsch U, Schachner M, Maeda N, Suzuki K, Popko B (1998) The cytoplasmic domain of the large myelin-associated glycoprotein isoform is needed for proper CNS but not peripheral nervous system myelination. J Neurosci 18:1970-1978.

GrandPré T, Nakamura F, Vartanian T, Strittmatter SM (2000) Identification of the Nogo inhibitor of axon regeneration as a Reticulon protein. Nature 403:439-444.

Habib AA, Gulcher JR, Högnason T, Zheng L, Stefánsson K (1998) The OMgp gene, a second growth suppressor within the NF1 gene. Oncogene 16:1525-1531.

Hata K, Fujitani M, Yasuda Y, Doya H, Saito T, Yamagishi S, Mueller BK, Yamashita T (2006) RGMa inhibition promotes axonal growth and recovery after spinal cord injury. J Cell Biol 173:47-58.

Hu F, Liu BP, Budel S, Liao J, Chin J, Fournier A, Strittmatter SM (2005) Nogo-A interacts with the Nogo-66 receptor through multiple sites to create an isoform-selective subnanomolar agonist. J Neurosci 25:5298-5304.

Huang JK, Phillips GR, Roth AD, Pedraza L, Shan W, Belkaid W, Mi S, Fex-Svenningsen A, Florens L, Yates JR 3rd, Colman DR (2005) Glial membranes at the node of Ranvier prevent neurite outgrowth. Science 310:1813-1817.

Ji B, Case LC, Liu K, Shao Z, Lee X, Yang Z, Wang J, Tian T, Shulga-Morskaya S, Scott M, He Z, Relton JK, Mi S (2008) Assessment of functional recovery and axonal sprouting in oligodendrocyte-myelin glycoprotein (OMgp) null mice after spinal cord injury. Mol Cell Neurosci 39:258-267.

Kim JE, Li S, GrandPré T, Qiu D, Strittmatter SM (2003) Axon regeneration in young adult mice lacking Nogo-A/B. Neuron 38:187-199.

Kim JE, Liu BP, Park JH, Strittmatter SM (2004) Nogo-66 receptor prevents raphespinal and rubrospinal axon regeneration and limits functional recovery from spinal cord injury. Neuron 44:439-451.

Laurén J, Hu F, Chin J, Liao J, Airaksinen MS, Strittmatter SM (2007) Characterization of myelin ligand complexes with neuronal Nogo-66 receptor family members. J Biol Chem 282:5715-5725.

Lee JK, Chan AF, Luu SM, Zhu Y, Ho C, Tessier-Lavigne M, Zheng B (2009) Reassessment of corticospinal tract regeneration in Nogo-deficient mice. J Neurosci 29:8649-8654.

Lemon RN (2008) Descending pathways in motor control. Annu Rev Neurosci 31:195-218.

Li C, Tropak MB, Gerlai R, Clapoff S, Abramow-Newerly W, Trapp B, Peterson A, Roder J (1994) Myelination in the absence of myelin-associated glycoprotein. Nature 369:747-750.

Li S, Liu BP, Budel S, Li M, Ji B, Walus L, Li W, Jirik A, Rabacchi S, Choi E, Worley D, Sah DW, Pepinsky B, Lee D, Relton J, Strittmatter SM (2004) Blockade of nogo-66, myelin-associated glycoprotein, and oligodendrocyte myelin glycoprotein by soluble nogo-66 receptor promotes axonal sprouting and recovery after spinal injury. J Neurosci 24:10511-10520.

Li S, Kim JE, Budel S, Hampton TG, Strittmatter SM (2005) Transgenic inhibition of Nogo-66 receptor function allows axonal sprouting and improved locomotion after spinal injury. Mol Cell Neurosci 29:26-39.

Liebscher T, Schnell L, Schnell D, Scholl J, Schneider R, Gullo M, Fouad K, Mir A, Rausch M, Kindler D, Hamers FP, Schwab ME (2005) Nogo-A antibody improves regeneration and locomotion of spinal cord-injured rats. Ann Neurol 58:706-719.

Liu BP, Fournier A, GrandPré T, Strittmatter SM (2002) Myelin-associated glycoprotein as a functional ligand for the Nogo-66 receptor. Science 297:1190-1193.

Liu BP, Cafferty WB, Budel SO, Strittmatter SM (2006) Extracellular regulators of axonal growth in the adult central nervous system. Philos Trans R Soc Lond B Biol Sci 361:1593-1610.

Löw K, Culbertson M, Bradke F, Tessier-Lavigne M, Tuszynski MH (2008) Netrin-1 is a novel myelin-associated inhibitor to axon growth. J Neurosci 28:1099-1108.

Mason P (2001) Contributions of the medullary raphe and ventromedial reticular region to pain modulation and other homeostatic functions. Annu Rev Neurosci 24:737-777.

McGee AW, Strittmatter SM (2003) The Nogo-66 receptor: focusing myelin inhibition of axon regeneration. Trends Neurosci 26:193-198.

McGee AW, Yang Y, Fischer QS, Daw NW, Strittmatter SM (2005) Experience-driven plasticity of visual cortex limited by myelin and Nogo receptor. Science 309:2222-2226.

McKerracher L, David S, Jackson DL, Kottis V, Dunn RJ, Braun PE (1994) Identification of myelin-associated glycoprotein as a major myelinderived inhibitor of neurite growth. Neuron 13:805-811.

McMahon SB, Armanini MP, Ling LH, Phillips HS (1994) Expression and coexpression of Trk receptors in subpopulations of adult primary sensory neurons projecting to identified peripheral targets. Neuron 12:11611171.

Mi S, Lee X, Shao Z, Thill G, Ji B, Relton J, Levesque M, Allaire N, Perrin S, Sands B, Crowell T, Cate RL, McCoy JM, Pepinsky RB (2004) LINGO-1 is a component of the Nogo-66 receptor/p75 signaling complex. Nat Neurosci 7:221-228.

Mikol DD, Stefansson K (1988) A phosphatidylinositol-linked peanut agglutinin-binding glycoprotein in central nervous system myelin and on oligodendrocytes. J Cell Biol 106:1273-1279.

Montag D, Giese KP, Bartsch U, Martini R, Lang Y, Blüthmann H, Karthigasan J, Kirschner DA, Wintergerst ES, Nave KA, Zielasek J, Toyka KV, Lipp H-P, Schachner M (1994) Mice deficient for the myelin-associated glycoprotein show subtle abnormalities in myelin. Neuron 13:229-246.

Moreau-Fauvarque C, Kumanogoh A, Camand E, Jaillard C, Barbin G, Boquet I, Love C, Jones EY, Kikutani H, Lubetzki C, Dusart I, Chédotal A (2003) The transmembrane semaphorin Sema4D/CD100, an inhibitor 
of axonal growth, is expressed on oligodendrocytes and upregulated after CNS lesion. J Neurosci 23:9229-9239.

Mukhopadhyay G, Doherty P, Walsh FS, Crocker PR, Filbin MT (1994) A novel role for myelin-associated glycoprotein as an inhibitor of axonal regeneration. Neuron 13:757-767.

Ng WP, Cartel N, Li C, Roder J, Lozano A (1996) Myelin from MAGdeficient mice is a strong inhibitor of neurite outgrowth. Neuroreport $7: 861-864$

Norton WT, Poduslo SE (1973) Myelination in rat brain: method of myelin isolation. J Neurochem 21:749-757.

Park JB, Yiu G, Kaneko S, Wang J, Chang J, He XL, Garcia KC, He Z (2005) A TNF receptor family member, TROY, is a coreceptor with Nogo receptor in mediating the inhibitory activity of myelin inhibitors. Neuron 45:345-351.

Pernet V, Joly S, Christ F, Dimou L, Schwab ME (2008) Nogo-A and myelinassociated glycoprotein differently regulate oligodendrocyte maturation and myelin formation. J Neurosci 28:7435-7444.

Prinjha R, Moore SE, Vinson M, Blake S, Morrow R, Christie G, Michalovich D, Simmons DL, Walsh FS (2000) Inhibitor of neurite outgrowth in humans. Nature 403:383-384.

Robak LA, Venkatesh K, Lee H, Raiker SJ, Duan Y, Lee-Osbourne J, Hofer T, Mage RG, Rader C, Giger RJ (2009) Molecular basis of the interactions of the Nogo-66 receptor and its homolog NgR2 with myelin-associated glycoprotein: development of NgROMNI-Fc, a novel antagonist of CNS myelin inhibition. J Neurosci 29:5768-5783.

Rünker AE, Little GE, Suto F, Fujisawa H, Mitchell KJ (2008) Semaphorin-6A controls guidance of corticospinal tract axons at multiple choice points. Neural Dev 3:34.

Savio T, Schwab ME (1989) Rat CNS white matter, but not gray matter, is nonpermissive for neuronal cell adhesion and fiber outgrowth. J Neurosci 9:1126-1133

Schnell L, Schwab ME (1990) Axonal regeneration in the rat spinal cord produced by an antibody against myelin-associated neurite growth inhibitors. Nature 343:269-272.

Schnell L, Schwab ME (1993) Sprouting and regeneration of lesioned corticospinal tract fibres in the adult rat spinal cord. Eur J Neurosci 5:1156-1171.

Schwab ME, Thoenen H (1985) Dissociated neurons regenerate into sciatic but not optic nerve explants in culture irrespective of neurotrophic factors. J Neurosci 5:2415-2423.

Shao Z, Browning JL, Lee X, Scott ML, Shulga-Morskaya S, Allaire N, Thill G, Levesque M, Sah D, McCoy JM, Murray B, Jung V, Pepinsky RB, Mi S (2005) TAJ/TROY, an orphan TNF receptor family member, binds Nogo-66 receptor 1 and regulates axonal regeneration. Neuron 45:353-359.
Silver J, Miller JH (2004) Regeneration beyond the glial scar. Nat Rev Neurosci 5:146-156.

Simonen M, Pedersen V, Weinmann O, Schnell L, Buss A, Ledermann B, Christ F, Sansig G, van der Putten H, Schwab ME (2003) Systemic deletion of the myelin-associated outgrowth inhibitor Nogo-A improves regenerative and plastic responses after spinal cord injury. Neuron 38:201-211.

Spillmann AA, Bandtlow CE, Lottspeich F, Keller F, Schwab ME (1998) Identification and characterization of a bovine neurite growth inhibitor (bNI-220). J Biol Chem 273:19283-19293.

Steward O, Zheng B, Tessier-Lavigne M (2003) False resurrections: distinguishing regenerated from spared axons in the injured central nervous system. J Comp Neurol 459:1-8.

Steward O, Zheng B, Banos K, Yee KM (2007) Response to: Kim et al., “Axon regeneration in young adult mice lacking Nogo-A/B." Neuron 38, 187-199. Neuron 54:191-195.

Syken J, Grandpre T, Kanold PO, Shatz CJ (2006) PirB restricts oculardominance plasticity in visual cortex. Science 313:1795-1800.

Szpara ML, Vranizan K, Tai YC, Goodman CS, Speed TP, Ngai J (2007) Analysis of gene expression during neurite outgrowth and regeneration. BMC Neurosci 8:100.

Venkatesh K, Chivatakarn O, Lee H, Joshi PS, Kantor DB, Newman BA, Mage R, Rader C, Giger RJ (2005) The Nogo-66 receptor homolog NgR2 is a sialic acid-dependent receptor selective for myelin-associated glycoprotein. J Neurosci 25:808-822.

Vourc'h P, Andres C (2004) Oligodendrocyte myelin glycoprotein (OMgp): evolution, structure and function. Brain Res Brain Res Rev 45:115-124.

Wang KC, Koprivica V, Kim JA, Sivasankaran R, Guo Y, Neve RL, He Z (2002) Oligodendrocyte-myelin glycoprotein is a Nogo receptor ligand that inhibits neurite outgrowth. Nature 417:941-944.

Wang X, Chun SJ, Treloar H, Vartanian T, Greer CA, Strittmatter SM (2002) Localization of Nogo-A and Nogo-66 receptor proteins at sites of axonmyelin and synaptic contact. J Neurosci 22:5505-5515.

Wang X, Baughman KW, Basso DM, Strittmatter SM (2006) Delayed Nogo receptor therapy improves recovery from spinal cord contusion. Ann Neurol 60:540-549.

Wolswijk G, Riddle PN, Noble M (1991) Platelet-derived growth factor is mitogenic for O-2Aadult progenitor cells. Glia 4:495-503.

Yiu G, He Z (2006) Glial inhibition of CNS axon regeneration. Nat Rev Neurosci 7:617-627.

Zheng B, Ho C, Li S, Keirstead H, Steward O, Tessier-Lavigne M (2003) Lack of enhanced spinal regeneration in Nogo-deficient mice. Neuron $38: 213-224$. 